\title{
Scriptura: treinta años de estudios literarios (1986-2016)
}

\author{
Mercedes ALONSO BRAVO y Julián ACEBRÓN RUIZ \\ Universitat de Lleida
}

\begin{abstract}
A guisa de recapitulación y balance - $\mathrm{y}$ también, ¿a qué negarlo?, con un punto de orgullo - ofrecemos aquí tres índices retrospectivos de las tres décadas que hogaño cumple Scriptura. El primero, un índice cronológico de los artículos publicados en cada número hasta la fecha, consigna entre corchetes las páginas inicial y última de cada contribución. El segundo es un índice de todas las personas - 227, con sus apellidos ordenados por abecé- que han colaborado con sus estudios. El tercero es un índice analítico — selectivo, no exhaustivo- de obras, autorías, movimientos estético-literarios, conceptos, motivos, temas y demás. En los dos últimos índices y al final de cada referencia figuran entre corchetes el número (o números, cuando se trata de un volumen doble o triple) de Scriptura en negrita y las páginas correspondientes del artículo.
\end{abstract}





\section{I. Índice cronológico de artículos}

$\mathrm{N}^{\circ} 1$ (1986)

ALEGRE, Celina

Ana Ozores y Fermín de Pas: biografías paralelas en La Regenta de Clarín [5-13]

GINÉ JANER, Marta

Radiografía de un ideal: la pasión amorosa de Bonifacio Reyes [15-23]

MARCO, Joaquín

La obra de León Felipe en el contexto de la poesía española [25-35]

PONT, Jaume

El Postismo: génesis, teoría y obra [37-47]

ROVIRA, Pere

La personalidad poética de Alfonso Costafreda [49-64]

JOVÉ, Jordi

"Así se fundó Leopoldo María Panero" [67-75]

HURTADO, Pilar

El humor y el absurdo en un capítulo de $R a$ yuela [77-89]

TOVAR, Paco

"Lucha hasta el alba" de Roa Bastos. Fábula restaurada de un texto recuperado [91-96] 
$N^{0} 2$ (1986)

ARMENGOL, Luis

BACARDÍ, Montserrat

BAYO, Emili

CABALLÉ, Anna

JOVÉ, Jordi

PONT, Jaume

SERNA ARNAIZ, Mercedes

TOVAR, Paco

CALERO FERNÁNDEZ, Ma Ángeles

LÓPEZ LÓPEZ, Matías

CEREZO MAGÁN, Manuel
La novela como confesión. (Lectura de Alexis de Marguerite Yourcenar) [5-9]

Acerca de la vida y la palabra en Compañera de hoy de Alfonso Costafreda [11-27]

Las antologías de poesía y la literatura española de la posguerra [29-37]

Aspectos de la literatura autobiográfica en España [39-49]

"Prosa para un fin de capítulo", un poema de Carlos Barral [51-61]

Una novela inédita de Eduardo Chicharro [63-73]

Cultura Universal y Cultura Española en José Martí [75-83]

Stravinsky y Carpentier: La consagración de la primavera [85-97]

El gran teatro del mundo, síntesis del dogmatismo trentino [99-109]

Sempronio Aselión y la incipiente crítica historiográfica romana [111-115]

Plutarco en la encrucijada lingüística greco-romana [117-123] 
$N^{0} 3$ (1987)

CEREZO MAGÁN, Manuel

LÓPEZ LÓPEZ, Matías

MARGARIT, Mònica

CALERO FERNÁNDEZ, Ma Ángeles

SALA VALLDAURA, Josep Maria

GONZÁLEZ, Lola

FÈRRIZ, M. Teresa

NÚÑEZ ESTEBAN, C.

y C. SAIZ

TOVAR, Paco

JOVÉ, Jordi

BAYO, Emili
El mundo del amor y Safo [5-13]

Virgilio, hombre y poeta del siglo XX [14-23]

Una isagoge para Ausiàs March: notas para la lectura del poema I [24-47]

La defensa del indio: presupuestos ideológicos previos a la obra literaria de Bartolomé de Las Casas [48-57]

Recursos cómicos no lingüísticos en González del Castillo [58-77]

Francisco de Aldana: un ejemplo de divina ebriedad de amor [78-91]

En torno al Martín Fierro. (El alcohol como generador de canto) [92-104]

La sensualidad fetichista en La Regenta [105-113]

Rubén Darío ha bebido, viva Darío [114-132]

Anotaciones a La pipa de kif de Valle-Inclán [133-147]

El escritor gandul: los relatos de Juan Marsé [148-166]

\section{$\mathrm{N}^{0} 4$ (1988)}
ALSINA, José
La poesía de Odisseas Elitis [5-8] 
GONZÁLEZ, Lola

JOVÉ, Jordi

BALCELLS, José María

SAMBLANCAT MIRANDA, Neus

FÈRRIZ ROURE, Teresa

CANUT, Concepció

y Alfred MANGUES

VILA, $\mathrm{M}^{\mathrm{a}}$ Nieves

SÁNCHEZ RODRÍGUEZ Alfonso

MAGRE, Jaume

TOVAR, Paco

CABALLÉ, Anna

PONT, Jaume
La metamorfosis del paisaje renacentista en la poesía de Francisco de Aldana [9-19]

Lacrimosidad y suspiros en la Diana de Montemayor [21-33]

Quevedo, traductor del griego [35-41]

El arte y el pueblo. (A propósito de la poética de Angel Samblancat) [43-47]

Hora de España: una nueva orientación estética [49-54]

La paradoja testimonial-surrealista o $L a$ novela del Indio Tupinamba de Eugenio Fernández Granell [55-68]

Mosén Jacinto y Mosén Millán. Papel de la Iglesia durante la guerra civil en la narrativa del exilio [69-75]

1928-1988: la "Oda a Platko" de Rafael Alberti, sesenta años después [77-90]

Thomas Bernhard: El Artista creado por la ciudad [91-95]

Alrededor de César Vallejo. Poemas póstumos [97-106]

Dos o tres cosas sobre la Historia Literaria [109-112]

La heterodoxia religiosa de Federico García Lorca. (Análisis y proyección de la obra juvenil inédita) [113-120] 


\section{No5 (1989)}

ACEBRÓN RUIZ, Julián

GONZÁLEZ, Lola

PONT, Anna María

SÁNCHEZ RODRÍGUEZ, Alfonso

FÈRRIZ, M. Teresa

ESTEVE Luis A.

y Gemma MAÑÁ DELGADO

RAMÍREZ ESCOTO, Rafael

ROVIRA, Pere

BAYO, Emili

BROCH, Àlex
"E como le vino el sueño soñava..." Experiencia onírica y aventura en Palmerín de Olivia [7-16]

Góngora según Quevedo: breve relación de una historia injuriosa [17-29]

Unamuno, el atípico [31-36]

Hay que darle forma a nuestro rostro: notas sobre una lectura del poeta surrealista Emilio Prados [37-41]

La revista Romance o la búsqueda de un proyecto común [43-50]

El final en la primera época de Ramon J. Sender: notas sobre Contraataque [51-64]

El mito del graal y el simbolismo alquímico en la Quête de Bronwyn de J. E. Cirlot [65-80]

Dos poemas contra el tiempo: "Nostalgie de la boue" y "De senectute", de Jaime Gil de Biedma [81-87]

Animalidad y justicia. (Apuntes para una lectura de Los Santos Inocentes) [89-98]

Aplicación del modelo actancial de A. J. Greimas a la lectura de Tiempo de silencio de Luis Martín Santos [99-114] 
JOVÉ, Jordi

TOVAR, Paco

$\mathrm{N}^{0}$ 6/7 (1990)

\section{Homenaje a Raquel Asún}

Coordinador: Jaume Pont

ASÚN, Raquel

SERÉS, Guillermo

MANERO SOROLLA, Ma Pilar

GONZÁLEZ, Lola

APARICIO MAYDEU, Javier

SALA VALLDAURA, Josep Maria

ACEREDA, Alberto
Los ajustes poéticos de Justo Navarro: Un aviador prevé su muerte [115-121]

La novela de la revolución mexicana en la narrativa hispanoamericana contemporánea [123-136]

Biobibliografía de Raquel Asún [9-11]

El amor como invención y descubrimiento [13-14]

Milicia-malicia en el Siglo de Oro: de la virtus a la cautela [15-23]

Ana de Jesús vista por Henri Bremond: un caso de comprensible incomprensión [25-40]

Fonosimbolismo y aliteración: Francisco de Aldana frente a la palabra poética [41-49]

Anotaciones sobre Calderón y la moda hagiográfica de su tiempo [51-56]

Estébanez Calderón como escritor romántico [57-63]

Del Don Juan al Tanhäuser: entre Zorrilla y Wagner [65-71] 
GUTIÉRREZ DÍAZ-BERNARDO, Esteban

MATEO, Eduardo

SOTELO VÁZQUEZ, Adolfo

SERNA ARNAIZ, Mercedes

CABALLÉ, Anna

SOTELO VÁZQUEZ, Marisa

RODRÍGUEZ-FISCHER, Ana

TOVAR, Paco

SÁNCHEZ RODRÍGUEZ, Alfonso

FORGAS BERDET, Esther

FERRER SOLÁ, Jesús
Gabriel Araceli como Pablos de Segovia. Ecos del Buscón en Trafalgar [73-81]

Análisis del final de dos novelas de Clarín [83-90]

En torno a Mi primera campaña (1893) de Rafael Altamira [91-104]

Breve recorrido sobre la prosa modernista de José Martí [105-114]

Formas de autobiografía en Rubén Darío [115-122]

La Escuela Popular de Sabiduría Superior de Machado y el Ideario de la Institución Libre de Enseñanza [123-131]

Un proyecto de Ortega y Gasset: la colección Vidas españolas e hispanoamericanas del siglo XIX [133-144]

Altazor, un poema creacionista de Vicente Huidobro [145-154]

El viaje literario en la poesía ultraísta de Oliverio Girondo [155-163]

Rostros y rastros en la poesía y en la obra de Pablo Neruda [165-174]

El concepto de las cosas en la poesía española contemporánea [175-180] 
NÚÑEZ ESTEBAN, C. y Neus

SAMBLANCAT MIRANDA

FÈRRIZ, M. Teresa

FERNÁNDEZ GUTIÉRREZ,

José María

BONET, Laureano

BALCELLS, José María

MIRALLES, Enrique

JOVÉ, Jordi

$N^{0} 8 / 9$ (1992)

\section{De Hispanoamérica}

Coordinador: Paco Tovar

ARETA MARIGÓ, Gemma

SERÉS, Guillermo
Federica Montseny: una visión ácrata de la literatura [181-187]

Ejemplaridad y tradición inmediata (A. Machado y F. García Lorca en el exilio español del 1939) [189-196]

El simbolismo de la luz en León Felipe [197-203]

Unos papeles olvidados de Gabriel Ferrater: Kafka, Josep Pla y la astucia literaria [205-213]

Claves de Las contracifras, de Rafael Ballesteros [215-221]

Beltenebros: las borrosas aristas de una memoria narrativa [223-227]

Acerca de La soledad era esto [229-232]
Un lenguaje que no cesa [9-15]

"Yo, Bernal Diaz..." Aspectos novelescos de la Historia verdadera de la conquista de la Nueva España [17-26] 
POUPENEY HART, Catherine

CASTRO, Javier de

ROVIRA, José Carlos

REISZ, Susana

BERG, Walter Bruno

SARFATI-ARNAUD, Monique

CORRAL, Will H.

RUFFINELLI, Jorge

TOVAR, Paco

COIRA, María

MORENO TURNER, Fernando
Literatura colonial hispanoamericana. En torno a la reorganización de un área disciplinaria [27-35]

Entre la literatura y la historia: estructura y contenido de los relatos de naufragios de los tiempos de la Carrera de Indias [37-51]

Clemente Althaus y la tradición italiana [53-72]

Para una historia de canon literario hispanoamericano: el indigenismo feminista de Clorinda Matto de Turner y la posteridad [73-82]

Nietzsche (en) De sobremesa. Modernidad y decadencia en la novela de José Asunción Silva [83-97]

El relato testimonial o cómo hacer hablar al otro [99-110]

La interpretación canónica y el testimonio de la Letrada [111-118]

Ángel Rama, Marcha, y la crítica literaria latinoamericana en los 60s [119-128]

Algo más que una simple historia senil: "El abuelo", de Mario Vargas Llosa [129-133]

Versiones narrativas en la construcción de un imaginario [135-150]

La historia recurrente y los nuevos cronistas de Indias (Sobre una modalidad de la novela hispanoamericana actual) [151-157] 
BITTOUN-DEBRUYNE, Nathalie

ACEBRÓN RUIZ, Julián

JOVÉ, Jordi

FUENTE, José Luis de la

EZQUERRO, Milagros

AÍNSA, Fernando

VICH FLÓREZ, Cynthia

SOLÀ, Pere

ESPEJO CALA, Carmen

SÁNCHEZ RODRÍGUEZ, Alfonso

CALABRESE, Elisa

BURGOS, Fernando

OCHANDO, Carmen
Hijo de hombre, versión femenina [159-170]

La aventura del fingido marqués de Guarany: una anécdota en la corte de Fernando VII escribe un episodio de Yo el Supremo [171-188]

Notas para Cien años de soledad. Extrañamientos del cuento [189-193]

Direcciones y carencias del narrador en $U n$ mundo para Julius de Alfredo Bryce Echenique [195-211]

El espejo de las ranas [213-218]

Cristina Peri Rossi: del otro lado de la puerta [219-227]

Entrevista a Cristina Peri Rossi [229-237]

Pablo Neruda y Louis Aragon: ¿una misma tragedia íntima? [239-248]

El espacio de la selva en los sonetos de José Eustasio Rivera [249-254]

La inmolación perpetua de Carlos Oquendo de Amat [255-265]

Encuentro con la poesía de un antipoeta: Alfredo Veiravé [267-281]

Raúl Zurita: hacia un nuevo logos poético [283-290]

Roque Dalton. Experiencia estética de la Revolución [291-296] 
LLARENA, Alicia

CURIEL, Rosario

DENIZ, Gerardo

FÈRRIZ, M. Teresa

MATEO, Eduardo

$\mathrm{N}^{0} 10$ (1994)

\section{Poesía actual}

Coordinador: Pere Rovira

ROVIRA, Pere

JIMÉNEZ MILLÁN, Antonio

RODRÍGUEZ, Juan Carlos

YANKE, Germán

JOVÉ, Jordi
De cuando echaron a rodar sus ojos verdes: para una lectura de la joven poesía cubana [297-323]

La literatura latinoamericana: propuestas para una periodización [325-333]

Literatura y exilio [335-340]

La revista literaria De mar a mar: la cultura española en la Argentina de los años cuarenta [341-357]

Dos problemas del exilio: géneros literarios y relación con los escritores del interior [359-368]
"El título de este número monográfico..." [9-10]

Un engaño menor: las generaciones literarias [13-35]

La poesía y la sílaba del no. (Notas para una aproximación a la Poética de la Experiencia) [37-52]

La figuración irónica [53-67]

La poesía en el sur y la luna como norte [69-74] 
PENA, Pere

CARRETERO, Ana

y Fernando HERVÁS

SÁNCHEZ RODRÍGUEZ, Alfonso

JOVÉ, Josep Ramon

MUÑOZ, Luis

PIQUERO, José Luis

GALLEGO, Vicente

GARCÍA, Álvaro

LUQUE, Aurora

MORA, Ángeles

SALVADOR, Álvaro

SALVAGO, Javier

LINARES, Abelardo

MESA TORÉ, José Antonio
La otra ciudad. (Los poetas y la ciudad del fin de siglo) [75-91]

Una ausencia: la poesía en clase de español lengua extranjera [93-95]

La importancia de llamarse García o la vuelta de Garcilaso [97-105]

Canciones que habitan poemas [107-112]

El buen discípulo de José Luis Piquero. Manual de instrucciones [p. 115]

Paisajes de Septiembre [116-119]

Música callada. La noche junto al álbum, de Álvaro García [120-121]

Aurora Luque [122]

Notas a La Dama Errante [123-124]

El cuerpo de la poesía [125-126]

Los mejores años, de Javier Salvago [127131]

Los espejos de Abelardo Linares [132-134]

Los ojos del extraño [135-136]

Joaquín Ríos, el nómada hospitalario [137139] 
RÍOS, Joaquín

JIMÉNEZ MILLÁN, Antonio

ROVIRA, Pere

FORTUNY, Francisco

VILLALBA, Juan Manuel

GARCÍA MONTERO, Luis

MARZAL, Carlos

BENÍTEZ REYES, Felipe

LAMILLAR, Juan

TRAPIELLO, Andrés

ALBORNOZ, Aurora de

DÍAZ DE CASTRO, Francisco J.
Pasión y control en Cielo rasante, de Francisco Fortuny de los Ríos [140-143]

El amigo imaginario: entre la pasión y el hastío [144-145]

Casa invadida, de Antonio Jiménez Millán [146-148]

Simbolismo de fondo en la poesía de Juan Manuel Villalba. Fondo, Juan Manuel Villalba [149-151]

Saber encontrar. El corazón azul del alumbrado, Benjamín Prado [152-153]

Carlos Marzal [154-157]

La perfecta compañía de Felipe Benítez [158-160]

Juan Lamillar, El paisaje infinito [161-163]

Andrés Trapiello: las verdades del solitario [164-166]

Divagaciones para un poeta moderno [167169]

Relectura de Paseo de los tristes [170-173]

Primera lectura de Habitaciones separadas [174-180] 
$\mathrm{N}^{0} 11$ (1996)

\section{Literatura del Siglo de Oro}

Coordinadora: Lola González

ACEBRÓN RUIZ, Julián

BACZYNSKA, Beata

BÉZIART, Florence

CARRASCO, Félix

DEFFIS DE CALVO, Emilia I.

GILBERT, Françoise

GONZÁLEZ, Lola

HERMENEGILDO, Alfredo

LAPLANA GIL, José Enrique
Del artificio narrativo a la digresión sermonaria. Dos singulares lances en los libros $\mathrm{V}$ y VI de Amadis [7-30]

Dos epitafios a Roma sepultada en sus ruinas: un epigrama polaco de Mikolaj Sep Szarzynski y un soneto español de Francisco de Quevedo [31-42]

Sobre algunos aspectos del silencio en cuatro comedias palatinas de Tirso de Molina [43-62]

De la "vida retirada" a Soledades de Góngora: convergencias y divergencias [63-82]

De la escritura merecida. Notas sobre el libro III del Persiles [83-91]

El Anticristo de Juan Ruiz de Alarcón: reelaboración de un mito por la dramatización [93-112]

Forma y significado de la tercería amorosa en Miguel de Cervantes [113-124]

El personaje espectador: teatro en el teatro del siglo XVII [125-139]

Un tratado de fisiognomía de 1650 [141-153] 
ORTIÑÁ, Maricel

POLO, Monique

PORQUERAS MAYO, Alberto

POUPENEY HART, Catherine
El retrato idealizado en la obra poética de Catalina Clara Ramírez de Guzmán (16181684) $[155-164]$

Lo literario en la obra poética de Antonio Pérez [165-178]

Impacto de El Príncipe Constante en la crítica hispanística (1972-1992) [179-189]

Diálogos y sátira en la Crónica de Felipe Guaman Poma de Ayala [191-201]

TEIJEIRO FUENTES, Miguel Ángel Galicia y los gallegos en la literatura española del Siglo de Oro [203-246]

PÉREZ TEIJÓN, Josefina

El tratamiento literario del cotidie morimur en la prosa de Fray Pedro de Vega [247-256]

No 12 (1996)

\section{La imagen de la mujer en la literatura}

Coordinadora: Ma Ángeles Calero Fernández

CALERO FERNÁNDEZ, Ma Ángeles Prólogo [7-12]

QUINTILLÁ ZANUY, Teresa Voces femeninas en el mito antiguo: el maleficio de un enigma [13-31]

OTERO VIDAL, Mercè

¿“Si adulterata, cur laudata...”? [33-49]

GÓMEZ-FERRER MORANT, Guadalupe

La educación de las mujeres en la novela de la Restauración [51-75] 
MATEU SERRA, Rosa $M^{\mathrm{a}}$

ALETTA DE SYLVAS, Graciela

MARTÍN MARTY, Laia

GINÉ JANER, Marta

SUÁREZ LAFUENTE, Ma Socorro

SANTA, Àngels

CALERO FERNÁNDEZ, Mángeles ratura escrita en español: una bibliografía

CALERO FERNÁNDEZ, Ma Ángeles La mujer en algunas literaturas occidentales:

ACEBRÓN RUIZ, Julián aproximativa [185-214] una aproximación bibliográfica [215-252]

Índices de Scriptura. 1986-1996 [253-303]

Álbum de familia: la máscara como instrumento de desmitificación [77-89]

Ser mujer en la escritura de Angélica Gorodischer [91-100]

La mujer en la ideología y la literatura del Novecentismo catalán [101-128]

Villiers: las muchas caras de Eva [129151]

La mujer como tema intertextual en la literatura contemporánea en la lengua inglesa [153171]

El desamor [173-184]

Análisis de las figuras femeninas en la lite-

$N^{\circ} 13$ (1997)

\section{Letradura. Estudios de literatura medieval}

Editor: Julián Acebrón Ruiz

WALTHAUS, Rina

Espacio y alienación en Grimalte y Gradissa de Juan de Flores [5-18] 
SERÉS, Guillermo

SALINAS ESPINOSA, Concepción

RICAPITO, Joseph V.

PIÑERO VALVERDE,

María de la Concepción

PARRILLA GARCÍA, Carmen

MONTOYA MARTÍNEZ, Jesús

LUCÍA MEGÍAS, José Manuel

FRANCO DURÁN, María Jesús

FERRER CHIVITE, Manuel

EISENBERG, Daniel

DOMÍNGUEZ, César
Una nota sobre el escolasticismo poético en el otoño de la Edad Media [19-31]

La pregunta poética "Non como quien se desvela" del bachiller Alfonso de la Torre [33-42]

La narratividad del romance de El Conde Dirlos [43-57]

Vida fronteriza en el Poema de Mio Cid: Medina y Molina [59-65]

La 'Exclamación de España' dirigida al arzobispo Carrillo. Un ejemplo de la fictio personnae al servicio del alegato político [67-99]

La caballería en Castilla. El Doctrinal de Cavalleros de Alonso de Cartagena y el Tít. XXI de la Partida II [101-113]

Caballero, escudero, peón. (Aproximación al mundo caballeresco del Libro del cavallero Zifar) [115-137]

Los manuales mitográficos medievales como fuente de transmisión de las fábulas antiguas [139-149]

Sobre las coplas llamadas "del tabefe", su autor y sus avatares [151-171]

Inexactitudes y misterios bibliográficos: las primeras ediciones de Primaleón [173-178]

"E contauan vna grand maravilla". Lo Maravilloso y sus fórmulas retóricas en los relatos de viajes medievales [179-191] 
CUESTA, María Luzdivina

CROSAS, Francisco

BIZARRI, Hugo O.

BELTRÁN, Rafael y Marta HARO

AMASUNO, Marcelino V.

ALONSO, Álvaro

ACEBRÓN RUIZ, Julián

No 14 (1998)

\section{EI "ensayo contemporáneo"}

Editor: Jordi Jové

JOVÉ, Jordi

LÓPEZ LÓPEZ, Matías
Notas sobre las relaciones paterno-filiales en la narrativa castellana medieval [193-206]

Las lecturas de doña Mencía: la iconografía del retablo de Santa Ana de la capilla del Condestable de la Catedral de Burgos [207-216]

Una nota textual a los Refranes que dizen las viejas tras el fuego a propósito del refrán "más vale traque que dios vos salue" [217-226]

Las fuentes de las enseñanzas a Pero Niño en El Victorial [227-251]

Etiología del morbo en la Epistola et regimen de pestilentia, de Alfonso de Córdoba (1348) [253-275]

“Ay, Fatimá!": Moras y cristianos en la lírica tradicional [277-284]

“¿Dormides o velades?” La vigilia del alma en los sueños milagrosos [285-314]
El "ensayo contemporáneo": presentación [7-8]

Ecos de Aselión en la praefatio de Tito Livio [11-16] 
SÁEZ MATEU, Ferran

RAMÍREZ ASENCIO, Jordi

LAFUERZADEL CERRO, Josep Anton

RIZOS JIMÉNEZ, Carlos Ángel

GENÍS GARCÍA, Joan

BUENO, Joan Manuel

MATEU SERRA, Rosa $\mathrm{M}^{\mathrm{a}}$

JOVÉ, Jordi

RUBINAT, Ramón

ROVIRA, Pere
La tradición occidental y su expresión agónica. Un replanteamiento de los orígenes del ensayo [17-30]

Descartes y la aporía de la escritura filosófica [31-45]

Acerca de los mitos prometeico y fáustico en la tradición cultural de occidente [49-64]

Sobre un ensayo de ensayo: Mi primer ensayo de Casta Esteban [65-71]

Con El defensor de Pedro Salinas [73-78]

Es extraño vivir con las palabras... [79-89]

En torno al silencio [93-102]

Notas de lectura sobre Walter Benjamin [103-112]

Pruebas de ensayo en José Saramago [113125]

Contra el tiempo banquero [127-128]

No 15 (1999)

Risas y sonrisas en el teatro de los siglos XVIII y XIX

Editor: Josep M. Sala Valldaura

SALA VALLDAURA, Josep Maria Presentación [7-10]

CHECA BELTRÁN, José Poética de la risa [11-27] 
ÁLVAREZ BARRIENTOS, Joaquín

HUERTA CALVO, Javier

ROMERO FERRER, Alberto

RÍOS CARRATALÁ, Juan A.

PÉREZ MAGALLÓN, Jesús

CAÑAS MURILLO, Jesús

GARCÍA GARROSA, María Jesús

DEACON, Philip

GINÉ JANER, Marta

THATCHER GIES, David

SANTA, Àngels
Risa e "ilusión" escénica. Más sobre el actor en el siglo XVIII [29-50]

Comicidad y marginalidad en el sainete dieciochesco [51-75]

La tradición del sainete andaluz en el teatro cómico del siglo XIX [77-88]

Las parodias del melólogo: Samaniego frente a Iriarte [89-98]

Risa "costumbrista", carcajada romántica (De Zamora y Zorrilla) [99-120]

Humor y drama en El asombro de Jerez, Juana la Rabicortona, de José Cañizares [121-131]

La comicidad de La Cecilia, "drama" de Luciano F. Comella [133-144]

La comicidad de Doña Irene en El sí de las niñas de Leandro Fernández de Moratín [145-158]

El intertexto cultural español como motor de la sonrisa: Le théâtre de Clara Gazul [159-168]

"Mujer como Dios manda": antifeminismo y risa en Una mujer literata (1851), de Gutiérrez de Alba [169-176]

De la novela popular al melodrama. El ejemplo del Bossu de Paul Féval [177-189] 
$\mathrm{N}^{0} 16(2001)$

\section{El cuento español en el siglo XIX. Autores raros y olvidados}

Editor: Jaume Pont

PONT, Jaume

Presentación [7-8]

DÍAZ LARIOS, Luis F.

Notas para una poética del cuento romántico en verso (con algunos ejemplos) [9-23]

AMORES, Montserrat

Cuentos de vieja, de Juan de Ariza. La primera colección de cuentos folclóricos españoles [25-46]

TRANCÓN LAGUNAS, Montserrat

“El puñal” de Augusto Ferrán [47-56]

PONT, Jaume

Claves expresivas de la ironía en la narrativa "estrambótica" de Antonio Ros de Olano [57-87]

RUBIO CREMADES, Enrique

ROAS, David

JOVÉ, Jordi

AYALA, M ${ }^{\mathrm{a}}$ de los Ángeles

JURADO ZAFRA, Pepi
Afinidades entre el género cuento y el cuadro de costumbres: Carlos Frontaura [89-101]

Entre cuadros, espejos y sueños misteriosos. La obra fantástica de Pedro Escamilla [103-118]

Fantasía y humor en los Cuentos de Fernández Bremón [119-132]

Una docena de cuentos, primera recopilación de cuentos de Narciso Campillo y Correa [133-148]

De "Maximino Maury" a José M. Matheu [149-156] 
LATORRE, Yolanda

EZAMA GIL, Ángeles
El espíritu como búsqueda en los cuentos de J. O. Picón [157-170]

Blanca de los Ríos, escritora de cuentos [171-187]

$N^{0} 17$ (2002)

\section{Estudios sobre el teatro del Siglo de Oro}

Editora: Lola González

ALONSO ASENJO, Julio

ASZYK, Urszula

BACZYNSKA, Beata

BOLAÑOS DONOSO, Piedad
Alcides alegórico: Máscara o mojiganga estudiantil por el triunfo de Felipe $\mathrm{V}$ en Villaviciosa (1710) [7-31]

"Qué ves en aquesta gruta" (sobre el texto y la puesta en escena de dos cuadros de La aurora en Copacabana de Pedro Calderón de la Barca) [33-46]

Polonia y el mar: en torno al verso 1430 de La vida es sueño de Pedro Calderón de la Barca [47-63]

De cómo hostigó la Iglesia el teatro de Sevilla y su Arzobispado (1679-1731) [65-87]

DOMÍNGUEZ MATITO, Francisco

ESPEJO, Javier
La Fortuna (crítica) de un ingenio. Álvaro Cubillo de Aragón [89-112)

Algunos aspectos sobre la construcción del personaje en el teatro conservado de Hernán López de Yanguas (1487-¿?) [113-131] 
FERRER VALLS, Teresa

GIORDANO GRAMEGNA, Anna

GONZÁLEZ, Lola

HERMENEGILDO, Alfredo

LOBATO, María Luisa

NAVARRO DURÁN, Rosa

PORQUERAS MAYO, Alberto

DE SALVO, Mimma
Actores del siglo XVII: los hermanos Valenciano y Juan Jerónimo Almella [133-159]

La Fantesca de Giambattista della Porta. De la comedia literaria a la comedia teatral [161-176]

María de Navas: bosquejo biográfico de una controvertida actriz de la escena española de finales del siglo XVII [177-209]

Usos de la metateatralidad: las comedias de Lope de Rueda [211-225]

Fiestas teatrales al infante Felipe Próspero (1657-1661) y edición del baile "Los Juan Ranas" (XI-1658) [227-261]

Dos burladores. Don Juan Tenorio, en la estela de Eneas [263-277]

La admiración por Calderón en la España del siglo XVII [279-292]

Apodos de los actores del Siglo de Oro: procedimientos de transmisión [293-318]

TEIJEIRO FUENTES, Miguel Ángel Los Personajes de El Pompeyo de Mesa a la luz de la Farsalia de Lucano [319-333]

$N^{0} 18$ (2005)

\section{Monográfico Salvador Dalí}

Editores: Jordi Jové, Miquel Visa

VISA, Miquel

Presentación [7-8] 
NOT, Anton

ANDERSON, Andrew A.

CARRERAS, Anna

CIRLOT, Lourdes

LÁZARO DOCÍO, Jesús

FERNÁNDEZ, Víctor

MAS PEINADO, Ricard

PLANA, Lorenzo

PLAYÀ MASET, Josep

SANTAMARÍA DE MINGO, Vicent

VISA, Miquel
“Corazón bleu y coeur azul”: Dalí y Lorca en diálogo [13-23]

Dalí disidente: entre el juicio de Francesc Pujols y la locura controlada del surrealismo [25-39]

Aproximación a dos poemas de Dalí: El gran Masturbador y La metamorfosis de Narciso [41-47]

El Narcisismo creador daliniano. Análisis del poema y el cuadro de El gran masturbador [49-63]

Tardes d'estiu: un diálogo entre la obra literaria y la pintura [65-69]

La construcción de un personaje [71-73]

La egregia furia de la curación de la locura [75-79]

El preso Salvador Dalí [81-85]
La actividad poética de Salvador Dalí en relación con la controversia del automatismo surrealista [87-99]

Las llaves de San Sebastián [101-113]

Reseñas [115-128] 
$N^{0} 19 / 20(2008)$

\section{Mujer y género en las letras hispánicas}

Editor: Rafael M. Mérida Jiménez

MÉRIDA JIMÉNEZ, Rafael M. Presentación [7-8]

HUTCHESON, Gregory S. L L Iberia queer, nuevamente [9-20]

DANGLER, Jean Sueño de imperio y de masculinidad en la Estoria de Espanna [21-35]

ARBIZU-SABATER, Victoria

FERRÚS ANTÓN, Beatriz

MÉRIDA JIMÉNEZ, Rafael M.

SALA VALLDAURA, Josep Maria

ASENSI PÉREZ, Manuel

CLÚA GINÉS, Isabel

NÁTER, Miguel Ángel
Paratexto sexual y sátira misógina en la Carajicomedia [37-56]

Crea que andamos hechizadas la una con la otra. Mujeres en el entorno de Santa Teresa (cuerpos y almas) [57-73]

El Quijote de Avellaneda y la tradición amadisiana (sobre una "puta vieja del tiempo de Mari Castaña") [75-93]

El erotismo y la modernidad de La petimetra, de Nicolás Fernández de Moratín [95-110]

Unsex me here: Tristana y la pasión [111139]

Amores clínicos: cuerpo, enfermedad y erotismo en Las neuróticas, de Alberto Insúa [141-161]

De míticas mujeres: asedio al erotismo de la poesía modernista en Puerto Rico [163-185] 
GARCÍA PIEDRA, Juan Carlos

CATELLI, Nora

TORRAS, Meri
Género gramatical y género erótico en la poesía de Rafael de León [187-199]

Espacio público y alianza masculina en la vida americana: José Lezama Lima [201-218]

Cuerpos interrogantes, rescrituras queer. Melalcor, de Flavia Company [219-237]

CERVANTES HERNÁNDEZ, Carlos y José SANTAANA PORRAS ALCOCER Los mártires del "Freeway": la máscara de la normalidad [239-256]

TURIEL, Josep M.

La edición y el acceso a la literatura y los materiales GLTBQ [257-280]

$\mathbf{N}^{0} 21 / 22(2011)$

Señas de Paraguay

Editores: Paco Tovar y Maria Gabriella Dionisi

TOVAR, Paco

y Maria Gabriella DIONISI Introducción [7-8]

RODRÍGUEZ-ALCALÁ, Carolina Apuntes para una historia de la escritura en guaraní: el estatuto y la circulación del texto en las misiones jesuíticas [9-32]

ANDREU, Jean L.

Lecturas paraguayas, casi memorias (I) [33-49]

FERRER, Renée

Ejes temáticos de la narrativa paraguaya [51-59] 
PARTYKA, Betsy

ROLDÁN, Ignacio

DIONISI, Maria Gabriella

FERNÁNDEZ, Miguel Ángel

ESPÍNOLA, Lourdes

CASOLA, Augusto

MENDOZA, Justo G.

MATEO DEL PINO, Ángeles

EZQUERRO, Milagros

NAVASCUÉS, Javier de

FOLLIN-TARROUX, Christiane

MORENO, Fernando

AÍNSA, Fernando
Desde lo oculto hacia la concientización: la naturaleza en la narrativa paraguaya contemporánea entre 1950-2000 [61-78]

El espacio insular idealizado [79-96]

El desencanto democrático como nueva frontera de la literatura [97-109]

Vanguardismo, posvanguardismo y modernidad en la poesía paraguaya [111-123]

Poesía femenina del Paraguay [125-138]

El erotismo en la poesía femenina del Paraguay [139-151]

Aporte de Rafael Barrett a la literatura social paraguaya [153-171]

Paisaje de los sueños o poética de la ensoñación en Josefina Plá [173-190]

La madre marchita de Josefina Plá [191200]

Secreto perverso y deseo mimético en $L a$ Babosa de Gabriel Casaccia [201-214]

Polifonía textual e "identidad narrativa" en Hijo de hombre de Augusto Roa Bastos. [215-246)

Yo el Supremo, una poética de la seducción [247-257]

La ley del talión en la selva paraguaya: los cuentos de Rubén Bareiro Saguier [259-273] 
GRILLO, Rosa Maria

LANGA, Mar

HALADYNA, Ronald

MARINI, Enrique
El imposible diálogo con el hombre de Renée Ferrer [275-290]

En la piel de la amante. Mujeres a la sombra del poder en El peluquero francés y $L a$ Querida [291-308]

La visión cosmológica en la poesía de Renée Ferrer [309-317]

Leyendo a Shirley Villalba en Penumbra hembra [319-327]

$N^{0} 23 / 24 / 25(2016)$

Translatio \& compilatio en la Baja Edad Media

Editores: Julián Acebrón Ruiz y Mercedes Alonso Bravo

ACEBRÓN RUIZ, Julián

y Mercedes ALONSO BRAVO

Presentación [7]

ALONSO BRAVO, Mercedes

Translatio et compilatio en la Flor de las ystorias de Orient, de Juan Fernández de Heredia [11]

IGLESIAS-ZOIDO, J. Carlos

El Tucídides de Heredia en el contexto de las antologías medievales de discursos historiográficos [43]

SANZ JULIÁN, María

La Crónica Troyana de Juan Fernández de Heredia como amalgama de géneros [65]

ACEBRÓN RUIZ, Julián

El caballero blanco y el emperador Canguis en la tercera partida de la Flor de las ystorias de Orient [93] 
CEREZO MAGÁN, Manuel

PICHEL, Ricardo

ZUBILLAGA, Carina

LAMPURLANÉS, Isaac

RECIO, Roxana

MATERNI, Marta

MATERNI, Marta, Mercedes ALONSO BRAVO y Julián ACEBRÓN RUIZ (eds.)

ALONSO BRAVO, Mercedes y Julián ACEBRÓN RUIZ
Juan Fernández de Heredia y Plutarco. Las Vidas Paralelas [121]

La eclosión de la materia clásica en las letras peninsulares bajomedievales. Compilaciones troyanas no autónomas [155]

Prácticas de lectura y escritura medieval en la compilación de las historias piadosas del Ms. Esc. h-i-13 [177]

RODRÍGUEZ MESA, Francisco José Koiné, ma non troppo. Apuntes acerca de la lengua de algunos autores presentes en el Cansonero del Conde de Popoli [195]

Del Ab urbe condita de Tito Livio al Scipió e Anibal de Antoni Canals [213]

Algunas puntualizaciones sobre el fragmento de Valter y Griselda del Ms. 89 de la Universidad de Barcelona [235]

Afloramientos textuales: el Alejandro recobrado (Firenze, Plut.36sin.7) [255]

Facsímil del Ms. Plut.36sin.7 de la Biblioteca Medicea Laurenziana (Florencia) [315]

Scriptura: treinta años de estudios literarios (1986-2016) [389] 



\section{II. Índice alfabético de colaboradores}

ACEBRÓN RUIZ, Julián

ACEBRÓN RUIZ, Julián

ACEBRÓN RUIZ, Julián

ACEBRÓN RUIZ, Julián

ACEBRÓN RUIZ, Julián

ACEBRÓN RUIZ, Julián

y Mercedes ALONSO BRAVO

ACEBRÓN RUIZ, Julián
“E como le vino el sueño soñava..." Experiencia onírica y aventura en Palmerín de Olivia [5, 7-16]

La aventura del fingido marqués de Guarany: una anécdota en la corte de Fernando VII escribe un episodio de Yo el Supremo $[8 / 9,171-188]$

Del artificio narrativo a la digresión sermonaria. Dos singulares lances en los libros V y VI de Amadis [11, 7-30]

Índices de Scriptura. 1986-1996 [12, 253 303]

“¿Dormides o velades?” La vigilia del alma en los sueños milagrosos [13, 285314]

Presentación [23/24/25, 7-9]

El caballero blanco y el emperador Canguis en la tercera partida de la Flor de las ystorias de Orient [23/24/25, 93-119] 
ACEBRÓN RUIZ, Julián

Mercedes ALONSO BRAVO

y Marta MATERNI (eds.)

ACEBRÓN RUIZ, Julián

y Mercedes ALONSO BRAVO

ACEREDA, Alberto

AÍNSA, Fernando

AÍNSA, Fernando

ALBORNOZ, Aurora de

ALEGRE, Celina

ALETTA DE SYLVAS, Graciela

ALONSO, Álvaro

ALONSO ASENJO, Julio

ALONSO BRAVO, Mercedes

y Julián ACEBRÓN RUIZ
Facsímil del Ms. Plut.36sin.7 de la Biblioteca Medicea Laurenziana (Florencia) [23/24/25, 315-374]

Scriptura: treinta años de estudios literarios (1986-2016) [23/24/25, 389-514]

Del Don Juan al Tanhäuser: entre Zorrilla y Wagner [6/7, 65-71]

Cristina Peri Rossi: del otro lado de la puerta [8/9, 219-227]

La ley del talión en la selva paraguaya: los cuentos de Rubén Bareiro Saguier [21/22, 259-273]

Relectura de Paseo de los tristes [10, 170173]

Ana Ozores y Fermín de Pas: biografías paralelas en La Regenta de Clarín [1, 5-13]

Ser mujer en la escritura de Angélica Gorodischer [12, 91-100]

“Ay, Fatimá!”: Moras y cristianos en la lírica tradicional [13, 277-284]

Alcides alegórico: Máscara o mojiganga estudiantil por el triunfo de Felipe V en Villaviciosa (1710) [17, 7-31]

Presentación [23/24/25, 7-9] 
ALONSO BRAVO, Mercedes

ALONSO BRAVO, Mercedes

Julián ACEBRÓN RUIZ

y Marta MATERNI (eds.)

ALONSO BRAVO, Mercedes y Julián ACEBRÓN RUIZ

ALSINA, José

ÁLVAREZ BARRIENTOS, Joaquín

AMASUNO, Marcelino V.

AMORES, Montserrat

ANDERSON, Andrew A.

ANDREU, Jean L.

APARICIO MAYDEU, Javier

ARBIZU-SABATER, Victoria
Translatio et compilatio en la Flor de las ystorias de Orient, de Juan Fernández de Heredia [23/24/25, 11-41]

Facsímil del Ms. Plut.36sin.7 de la Biblioteca Medicea Laurenziana (Florencia) [23/24/25, 315-374]

Scriptura: treinta años de estudios literarios (1986-2016) [23/24/25, 389-514]

La poesía de Odisseas Elitis [4, 5-8]

Risa e "ilusión” escénica. Más sobre el actor en el siglo XVIII [15, 29-50]

Etiología del morbo en la Epistola et regimen de pestilentia, de Alfonso de Córdoba (1348) [13, 253-275]

Cuentos de vieja, de Juan de Ariza. La primera colección de cuentos folclóricos españoles [16, 25-46]

"Corazón bleu y coeur azul": Dalí y Lorca en diálogo [18, 13-23]

Lecturas paraguayas, casi memorias (I) [21/22, 33-49]

Anotaciones sobre Calderón y la moda hagiográfica de su tiempo [6/7, 51-56]

Paratexto sexual y sátira misógina en la Carajicomedia [19/20, 37-56] 
ARETA MARIGÓ, Gemma

ARMENGOL, Luis

ASÚN, Raquel

ASZYK, Urszula

AYALA, Mª de los Ángeles

BACARDÍ, Montserrat

BACZYNSKA, Beata

BACZYNSKA, Beata

BALCELLS, José María

BALCELLS, José María

BAYO, Emili
Un lenguaje que no cesa $[\mathbf{8} / \mathbf{9}, 9-15]$

La novela como confesión (lectura de Alexis de Marguerite Yourcenar) [2, 5-9]

El amor como invención y descubrimiento [6/7, 13-14]

"Qué ves en aquesta gruta" (sobre el texto y la puesta en escena de dos cuadros de $L a$ aurora en Copacabana de Pedro Calderón de la Barca) [17, 33-46]

Una docena de cuentos, primera recopilación de cuentos de Narciso Campillo y Correa [16, 133-148]

Acerca de la vida y la palabra en Compañera de hoy de Alfonso Costafreda [2, 11-27]

Dos epitafios a Roma sepultada en sus ruinas: un epigrama polaco de Mikolaj Sep Szarzynski y un soneto español de Francisco de Quevedo [11, 31-42]

Polonia y el mar: en torno al verso 1430 de La vida es sueño de Pedro Calderón de la Barca [17, 47-63]

Quevedo, traductor del griego [4, 35-41]

Claves de Las contracifras, de Rafael Ballesteros [6/7, 215-221]

Las antologías de poesía y la literatura española de la posguerra [2, 29-37] 
BAYO, Emili

BAYO, Emili

BAYO, Emili

BELTRÁN, Rafael y Marta HARO

BENÍTEZ REYES, Felipe

BERG, Walter Bruno

BÉZIART, Florence

BITTOUN-DEBRUYNE, Nathalie

BIZARRI, Hugo O.

BOLAÑOS DONOSO, Piedad

BONET, Laureano
El escritor gandul: los relatos de Juan Marsé [3, 148-166]

La guerra de la posguerra [4, 121-123]

Animalidad y justicia. (Apuntes para una lectura de Los Santos Inocentes) [5, 89-98]

Las fuentes de las enseñanzas a Pero Niño en El Victorial [13, 227-251]

Juan Lamillar, El paisaje infinito [10, 161163]

Nietzsche (en) De sobremesa. Modernidad y decadencia en la novela de José Asunción Silva [8/9, 83-97]

Sobre algunos aspectos del silencio en cuatro comedias palatinas de Tirso de Molina $[4,43-62]$

Hijo de hombre, versión femenina [8/9, 159-170]

Una nota textual a los Refranes que dizen las viejas tras el fuego a propósito del refrán "más vale traque que dios vos salue" [13, 217-226]

De cómo hostigó la Iglesia el teatro de Sevilla y su Arzobispado (1679-1731) [17, 65-87]

Unos papeles olvidados de Gabriel Ferrater: Kafka, Josep Pla y la astucia literaria $[6 / 7,205-213]$ 
BROCH, Àlex

BUENO, Joan Manuel

BURGOS, Fernando

CABALLÉ, Anna

CABALLÉ, Anna

CABALLÉ, Anna

CALABRESE, Elisa
Aplicación del modelo actancial de A. J. Greimas a la lectura de Tiempo de silencio de Luis Martín Santos [5, 99-114]

Es extraño vivir con las palabras... [14, 79-89]

Raúl Zurita: hacia un nuevo logos poético [8/9, 283-290]

Aspectos de la literatura autobiográfica en España [2, 39-49]

Dos o tres cosas sobre la Historia Literaria $[4,109-112]$

Formas de autobiografía en Rubén Darío $[6 / 7,115-122]$

Encuentro con la poesía de un antipoeta: Alfredo Veiravé [8/9, 267-281]

CALERO FERNÁNDEZ, Ma Ángeles El gran teatro del mundo, síntesis del dogmatismo trentino $[2,99-109]$

CALERO FERNÁNDEZ, $\mathrm{M}^{\mathrm{a}}$ Ángeles La defensa del indio: Presupuestos ideológicos previos a la obra literaria de Bartolomé de las Casas [3, 48-57]

CALERO FERNÁNDEZ, Ma Ángeles Prólogo [12, 7-12]

CALERO FERNÁNDEZ, Ma Ángeles Análisis de las figuras femeninas en la literatura escrita en español: una bibliografía aproximativa $[12,185-214]$

CALERO FERNÁNDEZ, Ma Ángeles La mujer en algunas literaturas occidentales: una aproximación bibliográfica [12, 215-252] 
CANUT, Concepció

y Alfred MANGUES

CAÑAS MURILLO, Jesús

CARRASCO, Félix

CARRERAS, Anna

CARRETERO, Ana

y Fernando HERVÁS

CASOLA, Augusto

CASTRO, Javier de

CATELLI, Nora

CEREZO MAGÁN, Manuel

CEREZO MAGÁN, Manuel
La paradoja testimonial-surrealista o La novela del Indio Tupinamba de Eugenio Fernández Granell [4, 55-68]

Humor y drama en El asombro de Jerez, Juana la Rabicortona, de José Cañizares [15, 121-131]

De la "vida retirada" a Soledades de Góngora: convergencias y divergencias [11, 63-82]

Dalí disidente: entre el juicio de Francesc Pujols y la locura controlada del surrealismo [18, 25-39]

Una ausencia: la poesía en clase de español lengua extranjera [10, 93-95]

El erotismo en la poesía femenina del Paraguay [21/22, 139-151]

Entre la literatura y la historia: Estructura y contenido de los relatos de naufragios de los tiempos de la Carrera de Indias [8/9, 37-51]

Espacio público y alianza masculina en la vida americana: José Lezama Lima [19/20, 201-218]

Plutarco en la encrucijada lingüística greco-romana $[2,117-123]$

El mundo del amor y Safo [3, 5-13] 
CEREZO MAGÁN, Manuel

Juan Fernández de Heredia y Plutarco. Las Vidas paralelas $[\mathbf{2 3} / \mathbf{2 4} / \mathbf{2 5}, 153]$

CERVANTES HERNÁNDEZ, Carlos

y J. SANTAANA PORRAS ALCOCER Los mártires del "Freeway": la máscara de la normalidad [19/20, 239-256]

CHECA BELTRÁN, José

CIRLOT, Lourdes

CLÚA GINÉS, Isabel

COIRA, María

CORRAL, Will H.

CROSAS, Francisco

CUESTA, María Luzdivina

CURIEL, Rosario

DANGLER, Jean
Poética de la risa [15, 11-27]

Aproximación a dos poemas de Dalí: El gran Masturbador y La metamorfosis de Narciso [18, 41-47]

Amores clínicos: cuerpo, enfermedad y erotismo en Las neuróticas, de Alberto Insúa [19/20, 141-161]

Versiones narrativas en la construcción de un imaginario [8/9, 135-150]

La interpretación canónica y el testimonio de la Letrada [8/9, 111-118]

Las lecturas de doña Mencía: la iconografía del retablo de Santa Ana de la capilla del Condestable de la Catedral de Burgos [13, 207-216]

Notas sobre las relaciones paterno-filiales en la narrativa castellana medieval [13, 193-206]

La literatura latinoamericana: propuestas para una periodización [8/9, 325-333]

Sueño de imperio y de masculinidad en la Estoria de Espanna [19/20, 21-35] 
DE LA FUENTE, José Luis

DE SALVO, Mimma

DEACON, Philip

DEFFIS DE CALVO, Emilia I.

DENIZ, Gerardo

DÍAZ DE CASTRO, Francisco J.

DÍAZ LARIOS, Luis F.

DIONISI Maria Gabriella

y Paco TOVAR

DIONISI, Maria Gabriella

DOMÍNGUEZ, César
Direcciones y carencias del narrador en $U n$ mundo para Julius de Alfredo Bryce Echenique [8/9, 195-211]

Apodos de los actores del Siglo de Oro: procedimientos de transmisión [17, 293-318]

La comicidad de Doña Irene en El sí de las niñas de Leandro Fernández de Moratín [15, 145-158]

De la escritura merecida. Notas sobre el 1ibro III del Persiles [11, 83-91]

Literatura y exilio [8/9, 335-340]

Primera lectura de Habitaciones separadas [10, 174-180]

Notas para una poética del cuento romántico en verso (con algunos ejemplos) [16, 9-23]

Introducción [21/22, 7-8]

El desencanto democrático como nueva frontera de la literatura [21/22, 97-109]

"E contauan vna grand maravilla". Lo Maravilloso y sus fórmulas retóricas en los relatos de viajes medievales [13, 179-191]

DOMÍNGUEZ MATITO, Francisco
La Fortuna (crítica) de un ingenio. Álvaro Cubillo de Aragón [17, 89-112] 
EISENBERG, Daniel

ESPEJO CALA, Carmen

ESPEJO, Javier

ESPÍNOLA, Lourdes

ESTEVE Luis A.

y Gemma MAÑÁ DELGADO

EZAMA GIL, Ángeles

EZQUERRO, Milagros

EZQUERRO, Milagros

FERNÁNDEZ GUTIÉRREZ, J. M.

FERNÁNDEZ, Miguel Ángel

FERNÁNDEZ, Víctor

FERRER, Renée
Inexactitudes y misterios bibliográficos: las primeras ediciones de Primaleón [13, 173-178]

El espacio de la selva en los sonetos de José Eustasio Rivera [8/9, 249-254]

Algunos aspectos sobre la construcción del personaje en el teatro conservado de Hernán López de Yanguas (1487-¿?) [17, 113-131]

Poesía femenina del Paraguay [21/22, 125 138]

El final en la primera época de Ramon J. Sender: notas sobre Contraataque [4, 51-64]

Blanca de los Ríos, escritora de cuentos [16, 171-187]

El espejo de las ranas [8/9, 213-218]

La madre marchita de Josefina Plá [21/22, 191-200]

El simbolismo de la luz en León Felipe $[6 / 7,197-203]$

Vanguardismo, posvanguardismo y modernidad en la poesía paraguaya [21/22, 111-123]

Tardes d'estiu: un diálogo entre la obra literaria y la pintura [18, 65-69]

Ejes temáticos de la narrativa paraguaya [21/22, 51-59] 
FERRER CHIVITE, Manuel

FERRER SOLÁ, Jesús

FERRER VALLS, Teresa

FÈRRIZ ROURE, Teresa

FÈRRIZ ROURE, Teresa

FÈRRIZ ROURE, Teresa

FÈRRIZ ROURE, Teresa

FÈRRIZ ROURE, Teresa

FERRÚS ANTÓN, Beatriz

FOLLIN-TARROUX, Christiane

FORGAS BERDET, Esther
Sobre las coplas llamadas "del tabefe", su autor y sus avatares [13, 151-171]

El concepto de las cosas en la poesía española contemporánea [6/7, 175-180]

Actores del siglo XVII: los hermanos Valenciano y Juan Jerónimo Almella [17, 133-159]

En torno al Martín Fierro. (El alcohol como generador de Canto) [3, 92-104]

Hora de España: una nueva orientación estética [4, 49-54]

La revista Romance o la búsqueda de un proyecto común [5, 43-50]

Ejemplaridad y tradición inmediata (A. Machado y F. García Lorca en el exilio español del 1939) [6/7, 189-196]

La revista literaria De mar a mar: la cultura española en la Argentina de los años cuarenta [8/9, 341-357]

Crea que andamos hechizadas la una con la otra. Mujeres en el entorno de Santa Teresa (cuerpos y almas) [19/20, 57-73]

Polifonía textual e "identidad narrativa" en Hijo de hombre de Augusto Roa Bastos. [21/22, 215-246]

Rostros y rastros en la poesía y en la obra de Pablo Neruda [6/7, 165-174] 
FORTUNY, Francisco

FRANCO DURÁN, María Jesús

GALLEGO, Vicente

GARCÍA, Álvaro

GARCÍA GARROSA, María Jesús

GARCÍA MONTERO, Luis

GARCÍA PIEDRA, Juan Carlos

GENÍS GARCÍA, Joan

GILBERT, Françoise

GINÉ JANER, Marta

GINÉ JANER, Marta

GINÉ JANER, Marta
Simbolismo de fondo en la poesía de Juan Manuel Villalba. Fondo, Juan Manuel Villalba [10, 149-151]

Los manuales mitográficos medievales como fuente de transmisión de las fábulas antiguas [13, 139-149]

Música callada. La noche junto al álbum, de Álvaro García [10, 120-121]

Aurora Luque $[\mathbf{1 0}, 122]$

La comicidad de La Cecilia, "drama" de Luciano F. Comella [15, 133-144]

Carlos Marzal [10, 154-157]

Género gramatical y género erótico en la poesía de Rafael de León [19/20, 187-199]

Con El defensor de Pedro Salinas [14, 73-78]

El Anticristo de Juan Ruiz de Alarcón: reelaboración de un mito por la dramatización [11, 93-112]

Radiografía de un ideal: La pasión amorosa de Bonifacio Reyes [1, 15-23]

Villiers: las muchas caras de Eva $[\mathbf{1 2}, 129$ 151]

El intertexto cultural español como motor de la sonrisa: Le théâtre de Clara Gazul [15, 159-168] 
GIORDANO GRAMEGNA, Anna

GÓMEZ-FERRER MORANT, Guadalupe

GONZÁLEZ, Lola

GONZÁLEZ, Lola

GONZÁLEZ, Lola

GONZÁLEZ, Lola

GONZÁLEZ, Lola

GONZÁLEZ, Lola

GRILLO, Rosa Maria
La Fantesca de Giambattista della Porta. De la comedia literaria a la comedia teatral $[17,161-176]$

La educación de las mujeres en la novela de la Restauración [12, 51-75]

Francisco de Aldana: Un ejemplo de divina ebriedad de amor [3, 78-91]

La metamorfosis del paisaje renacentista en la poesía de Francisco de Aldana [4, 9-19]

Góngora según Quevedo: breve relación de una historia injuriosa [5, 17-29]

Fonosimbolismo y aliteración: Francisco de Aldana frente a la palabra poética $[6 / 7$, 41-49]

Forma y significado de la tercería amorosa en Miguel de Cervantes [11, 113-124]

María de Navas: bosquejo biográfico de una controvertida actriz de la escena española de finales del siglo XVII [17, 177209]

El imposible diálogo con el hombre de Renée Ferrer [21/22, 275-290]

GUTIÉRREZ DÍAZ-BERNARDO, E. Gabriel Araceli como Pablos de Segovia. Ecos del Buscón en Trafalgar [6/7, 73-81]

HALADYNA, Ronald

La visión cosmológica en la poesía de Renée Ferrer [21/22, 309-317] 
HARO, Marta y Rafael BELTRÁN

HERMENEGILDO, Alfredo

HERMENEGILDO, Alfredo

HERVÁS, Fernando

y Ana CARRETERO

HUERTA CALVO, Javier

HURTADO, Pilar

HUTCHESON, Gregory S.

IGLESIAS-ZOIDO, J. Carlos

JIMÉNEZ MILLÁN, Antonio

JIMÉNEZ MILLÁN, Antonio

JOVÉ, Jordi

JOVÉ, Jordi
Las fuentes de las enseñanzas a Pero Niño en El Victorial [13, 227-251]

El personaje espectador: teatro en el teatro del siglo XVII [11, 125-139]

Usos de la metateatralidad: las comedias de Lope de Rueda [17, 211-225]

Una ausencia: la poesía en clase de español lengua extranjera [10, 93-95]

Comicidad y marginalidad en el sainete dieciochesco [15, 51-75]

El humor y el absurdo en un capítulo de Rayuela [1, 77-89]

La Iberia queer, nuevamente [19/20, 9-20]

El Tucídides de Heredia en el contexto de las antologías medievales de discursos historiográficos [23/24/25, 43-64]

Un engaño menor: las generaciones literarias [10, 13-35]

El amigo imaginario: entre la pasión y el hastío [10, 144-145]

“Así se fundó Leopoldo María Panero" [1, 67-75]

"Prosa para un fin de capítulo", un poema de Carlos Barral [2, 51-61] 
JOVÉ, Jordi

JOVÉ, Jordi

JOVÉ, Jordi

JOVÉ, Jordi

JOVÉ, Jordi

JOVÉ, Jordi

JOVÉ, Jordi

JOVÉ, Jordi

JOVÉ, Jordi

JOVÉ, Josep Ramon

JURADO ZAFRA, Pepi

LAFUERZA DEL CERRO, Josep Anton
Anotaciones a La pipa de kif de Valle-Inclán [3, 133-147]

Lacrimosidad y suspiros en la Diana de Montemayor [4, 21-33]

Los ajustes poéticos de Justo Navarro: $U n$ aviador prevé su muerte [5, 115-121]

Acerca de La soledad era esto [6/7, 229232]

Notas para Cien años de soledad. Extrañamientos del cuento [8/9, 189-193]

La poesía en el sur y la luna como norte $[\mathbf{1 0}, 69-74]$

El “ensayo contemporáneo": presentación $[14,7-8]$

Notas de lectura sobre Walter Benjamin [14, 103-112]

Fantasía y humor en los Cuentos de Fernández Bremón [16, 119-132]

Canciones que habitan poemas [10, 107-112]

De "Maximino Maury" a José M. Matheu $[16,149-156]$

Acerca de los mitos prometeico y fáustico en la tradición cultural de occidente [14, 49-64] 
LAMILLAR, Juan

LAMPURLANÉS, Isaac

LANGA, Mar

LAPLANA GIL, José Enrique

LATORRE, Yolanda

LÁZARO DOCÍO, Jesús

LINARES, Abelardo

LLARENA, Alicia

LOBATO, María Luisa

LÓPEZ LÓPEZ, Matías

LÓPEZ LÓPEZ, Matías
Andrés Trapiello: las verdades del solitario [10, 164-166]

Del Ab urbe condita de Tito Livio al Scipió e Anibal de Antoni Canals [23/24/25, 213 233]

En la piel de la amante. Mujeres a la sombra del poder en El peluquero francés y $L a$ Querida [21/22, 291-308]

Un tratado de fisiognomía de 1650 [11, 141-153]

El espíritu como búsqueda en los cuentos de J. O. Picón [16, 157-170]

El Narcisismo creador daliniano. Análisis del poema y el cuadro de El gran masturbador [18, 49-63]

Los ojos del extraño [10, 135-136]

De cuando echaron a rodar sus ojos verdes: para una lectura de la joven poesía cubana [8/9, 297-323]

Fiestas teatrales al infante Felipe Próspero (1657-1661) y edición del baile "Los Juan Ranas” (XI-1658) [17, 227-261]

Sempronio Aselión y la incipiente crítica historiográfica romana [2, 111-115]

Virgilio, hombre y poeta del Siglo XX [3, 14-23] 
LÓPEZ LÓPEZ, Matías

LUCÍA MEGÍAS, José Manuel

LUQUE, Aurora

MAGRE, Jaume

MANERO SOROLLA, Ma Pilar

MANGUES, Alfred y

Concepció CANUT
Ecos de Aselión en la praefatio de Tito Livio $[14,11-16]$

Caballero, escudero, peón. (Aproximación al mundo caballeresco del Libro del cavallero Zifar) [13, 115-137]

Notas a La Dama Errante [10, 123-124]

Thomas Bernhard: El Artista creado por la ciudad [4, 91-95]

Ana de Jesús vista por Henri Bremond: un caso de comprensible incomprensión [6/7, 25-40]

La paradoja testimonial-surrealista o $L a$ novela del Indio Tupinamba de Eugenio Fernández Granell [4, 55-68]

MAÑÁ DELGADO, Gemma y Luis A. ESTEVE

MARCO, Joaquín

MARGARIT, Mónica

MARINI, Enrique

MARTÍN MARTY, Laia
El final en la primera época de Ramon J. Sender: notas sobre Contraataque [5, 51-64]

La obra de León Felipe en el contexto de la poesía española [1, 25-35]

Una isagoge para Ausiàs March: Notas para la lectura del poema I [3, 24-47]

Leyendo a Shirley Villalba en Penumbra hembra [21/22, 319-327]

La mujer en la ideología y la literatura del Novecentismo catalán [12, 101-128] 
MARZAL, Carlos

MAS PEINADO, Ricard

MATEO DEL PINO, Ángeles

MATEO, Eduardo

MATEO, Eduardo

MATERNI, Marta

MATERNI, Marta

Julián ACEBRÓN RUIZ

y Mercedes ALONSO BRAVO (eds.) Facsímil del Ms. Plut.36sin.7 de la Biblioteca Medicea Laurenziana (Florencia) $[23 / 24 / 25,315-374]$

MATEU SERRA, Rosa $\mathrm{M}^{\mathrm{a}}$

MATEU SERRA, Rosa M ${ }^{\mathrm{a}}$

MENDOZA, Justo G.
La perfecta compañía de Felipe Benítez [10, 158-160]

La construcción de un personaje [18, 71-73]

Paisaje de los sueños o poética de la ensoñación en Josefina Plá [21/22, 173-190]

Análisis del final de dos novelas de Clarín [6/7, 83-90]

Dos problemas del exilio: géneros literarios y relación con los escritores del interior [8/9, 359-368]

Afloramientos textuales: el Alejandro recobrado (Firenze, Plut.36sin.7) [23/24/25, 255-313]
Álbum de familia: la máscara como instrumento de desmitificación [12, 77-89]

En torno al silencio [14, 93-102]

Aporte de Rafael Barrett a la literatura social paraguaya [21/22, 153-171]

MÉRIDA JIMÉNEZ, Rafael Manuel Presentación [19/20, 7-8]

MÉRIDA JIMÉNEZ, Rafael Manuel El Quijote de Avellaneda y la tradición amadisiana (sobre una "puta vieja del tiempo de Mari Castaña”) [19/20, 75-93] 
MESA TORÉ, José Antonio

MIRALLES, Enrique

MONTOYA MARTÍNEZ, Jesús

MORA, Ángeles

MORENO TURNER, Fernando

MORENO TURNER, Fernando

MUÑOZ, Luis

NÁTER, Miguel Ángel

NAVARRO DURÁN, Rosa

NAVASCUÉS, Javier de

NOT, Anton

NÚÑEZ ESTEBAN, C. y C. SAIZ
Joaquín Ríos, el nómada hospitalario [10, 137-139]

Beltenebros: las borrosas aristas de una memoria narrativa [6/7, 223-227]

La caballería en Castilla. El Doctrinal de Cavalleros de Alonso de Cartagena y el Tít. XXI de la Partida II [13, 101-113]

El cuerpo de la poesía [10, 125-126]

La historia recurrente y los nuevos cronistas de Indias (Sobre una modalidad de la novela hispanoamericana actual) $[\mathbf{8} / \mathbf{9}$, 151-157]

Yo el Supremo, una poética de la seducción [21/22, 247-257]

El buen discípulo de José Luis Piquero. Manual de instrucciones [10, 115]

De míticas mujeres: asedio al erotismo de la poesía modernista en Puerto Rico [19/20, 163-185]

Dos burladores. Don Juan Tenorio, en la estela de Eneas [17, 263-277]

Secreto perverso y deseo mimético en $L a B a$ bosa de Gabriel Casaccia [21/22, 201-214]

L'Esteticisme [18, 9-11]

La sensualidad fetichista en La Regenta [3, 105-113] 
NÚÑEZ ESTEBAN, C.

y Neus SAMBLANCAT MIRANDA Federica Montseny: una visión ácrata de la literatura [6/7, 181-187]

OCHANDO, Carmen

ORTIÑÁ, Maricel

OTERO VIDAL, Mercè

PARRILLA GARCÍA, Carmen

PARTYKA, Betsy

PENA, Pere

PÉREZ ASENSI, Manuel

PÉREZ MAGALLÓN, Jesús

PÉREZ TEIJÓN, Josefina

PICHEL GOTÉRREZ, Ricardo
Roque Dalton. Experiencia estética de la Revolución [8/9, 291-296]

El retrato idealizado en la obra poética de Catalina Clara Ramírez de Guzmán (16181684) $[11,155-164]$

¿«Si adulterata, cur laudata...»? [12, 33-49]

La 'Exclamación de España' dirigida al arzobispo Carrillo. Un ejemplo de la fictio personnae al servicio del alegato político [13, 67-99]

Desde lo oculto hacia la concientización: la naturaleza en la narrativa paraguaya contemporánea entre 1950-2000 [21/22, 61-78]

La otra ciudad. (Los poetas y la ciudad del fin de siglo) [10, 75-91]

Unsex me here: Tristana y la pasión [19/20, 111-139]

Risa "costumbrista", carcajada romántica (De Zamora y Zorrilla) [15, 99-120]

El tratamiento literario del cotidie morimur en la prosa de Fray Pedro de Vega [11, 247-256]

La eclosión de la materia clásica en las letras peninsulares bajomedievales. Compilaciones troyanas no autónomas $[\mathbf{2 3 / 2 4 / 2 5}$, 155-176] 
PIÑERO VALVERDE,

María de la Concepción

PIQUERO, José Luis

PLANA, Lorenzo

PLAYÀ MASET, Josep

POLO, Monique

PONT, Anna María

PONT, Jaume

PONT, Jaume

PONT, Jaume

PONT, Jaume

PONT, Jaume

PORQUERAS MAYO, Alberto

PORQUERAS MAYO, Alberto
Vida fronteriza en el Poema de Mio Cid: Medina y Molina [13, 59-65]

Paisajes de Septiembre [10, 116-119]

La egregia furia de la curación de la locura $[18,75-79]$

El preso Salvador Dalí [18, 81-85]

Lo literario en la obra poética de Antonio Pérez [11, 165-178]

Unamuno, el atípico [5, 31-36]

El Postismo: génesis, teoría y obra [1, 37-47]

Una novela inédita de Eduardo Chicharro [2, 63-73]

La heterodoxia religiosa de Federico García Lorca. (Análisis y proyección de la obra juvenil inédita) [4, 113-120]

Presentación [16, 7-8]

Claves expresivas de la ironía en la narrativa "estrambótica" de Antonio Ros de Olano $[16,57-87]$

Impacto de El Príncipe Constante en la crítica hispanística (1972-1992) [11, 179-189]

La admiración por Calderón en la España del siglo XVII [17, 279-292] 
POUPENEY HART, Catherine

POUPENEY HART, Catherine

QUINTILLÁ ZANUY, Teresa

RAMÍREZ ASENCIO, Jordi

RAMÍREZ ESCOTO, Rafael

RECIO, Roxana

REISZ, Susana

RICAPITO, Joseph V.

RÍOS CARRATALÁ, Juan Antonio

RÍOS, Joaquín

RIZOS JIMÉNEZ, Carlos
Literatura colonial hispanoamericana. En torno a la reorganización de un área disciplinaria $[\mathbf{8} / \mathbf{9}, 27-35]$

Diálogos y sátira en la Crónica de Felipe Guaman Poma de Ayala [11, 191-201]

Voces femeninas en el mito antiguo: el maleficio de un enigma $[\mathbf{1 2}, 13-31]$

Descartes y la aporía de la escritura filosófica [14, 31-45]

El mito del graal y el simbolismo alquímico en la Quête de Bronwyn de J. E. Cirlot $[5,65-80]$

Algunas puntualizaciones sobre el fragmento de Valter y Griselda del Ms.89 de la Universidad de Barcelona [23/24/25, 235254]

Para una historia de canon literario hispanoamericano: el indigenismo feminista de Clorinda Matto de Turner y la posteridad $[8 / 9,73-82]$

La narratividad del romance de $E l$ Conde Dirlos [13, 43-57]

Las parodias del melólogo: Samaniego frente a Iriarte [15, 89-98]

Pasión y control en Cielo rasante, de Francisco Fortuny de los Ríos [10, 140-143]

Sobre un ensayo de ensayo: Mi primer ensayo de Casta Esteban [14, 65-71] 
ROAS, David

RODRÍGUEZ, Juan Carlos
Entre cuadros, espejos y sueños misteriosos. La obra fantástica de Pedro Escamilla $[16,103-118]$

La poesía y la sílaba del no. (Notas para una aproximación a la Poética de la Experiencia) $[10,37-52]$

RODRÍGUEZ MESA, Francisco José Koiné, ma non troppo. Apuntes acerca de la lengua de algunos autores presentes en el Cansonero del Conde de Popoli [23/24/25, 195-211]

RODRÍGUEZ-ALCALÁ, Carolina

RODRÍGUEZ-FISCHER, Ana

ROLDÁN, Ignacio

ROMERO FERRER, Alberto

ROVIRA, José Carlos

ROVIRA, Pere

ROVIRA, Pere
Apuntes para una historia de la escritura en guaraní: el estatuto y la circulación del texto en las misiones jesuíticas [21/22, 9-32]

Un proyecto de Ortega y Gasset: la colección Vidas españolas e hispanoamericanas del siglo XIX [6/7, 133-144]

El espacio insular idealizado [21/22, 7996]

La tradición del sainete andaluz en el teatro cómico del siglo XIX [15, 77-88]

Clemente Althaus y la tradición italiana [8/9, 53-72]

La personalidad poética de Alfonso Costafreda [1, 49-64]

Dos poemas contra el tiempo: "Nostalgie de la boue" y "De Senectute", de Jaime Gil de Biedma [5, 81-87] 
ROVIRA, Pere

ROVIRA, Pere

ROVIRA, Pere

RUBINAT, Ramón

RUBIO CREMADES, Enrique

RUFFINELLI, Jorge

SÁEZ MATEU, Ferran

SAIZ, C. y C. NÚÑEZ ESTEBAN

SALA VALLDAURA, Josep Maria

SALA VALLDAURA, Josep Maria

SALA VALLDAURA, Josep Maria

SALA VALLDAURA, Josep Maria
"El título de este número monográfico..." [10, 9-10]

Casa invadida, de Antonio Jiménez Millán [10, 146-148]

Contra el tiempo banquero $[\mathbf{1 4}, 127-128]$

Pruebas de ensayo en José Saramago [14, 113-125]

Afinidades entre el género cuento y el cuadro de costumbres: Carlos Frontaura [16, 89-101]

Ángel Rama, Marcha, y la crítica literaria latinoamericana en los 60s [8/9, 119-128]

La tradición occidental y su expresión agónica. Un replanteamiento de los orígenes del ensayo [14, 17-30]

La sensualidad fetichista en La Regenta [3, 105-113]

Recursos cómicos no lingüísticos en González del Castillo [3, 58-77]

Estébanez Calderón como escritor romántico [6/7, 57-63]

Presentación [15, 7-10]

El erotismo y la modernidad de La petimetra, de Nicolás Fernández de Moratín [19/20, 95-110] 
SALINAS ESPINOSA, Concepción La pregunta poética "Non como quien se desvela" del bachiller Alfonso de la Torre $[13,33-42]$

SALVADOR, Álvaro

SALVAGO, Javier

SAMBLANCAT MIRANDA, Neus

SAMBLANCAT MIRANDA, Neus

y C. NÚÑEZ ESTEBAN

SÁNCHEZ RODRÍGUEZ, Alfonso

SÁNCHEZ RODRÍGUEZ, Alfonso

SÁNCHEZ RODRÍGUEZ, Alfonso

SÁNCHEZ RODRÍGUEZ, Alfonso

SÁNCHEZ RODRÍGUEZ, Alfonso

SANTA ANA PORRAS ALCOCER, J.

Carlos CERVANTES HERNÁNDEZ Los mártires del "Freeway": la máscara de la normalidad [19/20, 239-256]

SANTA, Àngels

El desamor [12, 173-184]
Los mejores años, de Javier Salvago [10, 127-131]

Los espejos de Abelardo Linares [10, 132134]

Federica Montseny: una visión ácrata de la literatura [6/7, 181-187]

1928-1988: la "Oda a Platko" de Rafael Alberti, sesenta años después $[4,77-90]$

Hay que darle forma a nuestro rostro: notas sobre una lectura del poeta surrealista Emilio Prados [5, 37-41]

El viaje literario en la poesía ultraísta de Oliverio Girondo [6/7, 155-163]

La inmolación perpetua de Carlos Oquendo de Amat [8/9, 255-265]

La importancia de llamarse García o la vuelta de Garcilaso [10, 97-105] tica de Angel Samblancat) [4, 43-47]

(1) 
SANTA, Àngels

De la novela popular al melodrama. El ejemplo del Bossu de Paul Féval [15, 177-189]

SANTAMARÍA DE MINGO, Vicent La actividad poética de Salvador Dalí en relación con la controversia del automatismo surrealista [18, 87-99]

SANZ JULIÁN, María

SARFATI-ARNAUD, Monique

SERÉS, Guillermo

SERÉS, Guillermo

SERÉS, Guillermo

SERNA ARNAIZ, Mercedes

SERNA ARNAIZ, Mercedes

SOLÀ, Pere

SOTELO VÁZQUEZ, Adolfo

SOTELO VÁZQUEZ, Marisa
La Crónica Troyana de Juan Fernández de Heredia como amalgama de géneros [23/24/25, 65-91]

El relato testimonial o cómo hacer hablar al otro $[\mathbf{8} / \mathbf{9}, 99-110]$

Milicia-malicia en el Siglo de Oro: de la virtus a la cautela $[6 / 7,15-23]$

"Yo, Bernal Diaz..." Aspectos novelescos de la Historia Verdadera de la conquista de la Nueva España [8/9, 17-26]

Una nota sobre el escolasticismo poético en el otoño de la Edad Media [13, 19-31]

Cultura Universal y Cultura Española en José Martí [2, 75-83]

Breve recorrido sobre la prosa modernista de José Martí [6/7, 105-114]

Pablo Neruda y Louis Aragon: ¿una misma tragedia íntima? [8/9, 239-248]

En torno a Mi primera campaña (1893) de Rafael Altamira [6/7, 91-104]

La Escuela Popular de Sabiduría Superior de Machado y el Ideario de la Institución Libre de Enseñanza [6/7, 123-131] 
SUÁREZ LAFUENTE, María Socorro La mujer como tema intertextual en la literatura contemporánea en la lengua inglesa $[12,153-171]$

TEIJEIRO FUENTES, Miguel Ángel Galicia y los gallegos en la literatura española del Siglo de Oro [11, 203-246]

TEIJEIRO FUENTES, Miguel Ángel Los Personajes de El Pompeyo de Mesa a la luz de la Farsalia de Lucano [17, 319-333]

THATCHER GIES, David

TORRAS, Meri

TOVAR, Paco

TOVAR, Paco

TOVAR, Paco

TOVAR, Paco

TOVAR, Paco

TOVAR, Paco
"Mujer como Dios manda": antifeminismo y risa en Una mujer literata (1851), de Gutiérrez de Alba [15, 169-176]

Cuerpos interrogantes, rescrituras queer. Melalcor, de Flavia Company [19/20, 219-237]

Lucha hasta el Alba de Roa Bastos. Fábula restaurada de un texto recuperado [1,91-96]

Stravinsky y Carpentier: La consagración de la primavera [2, 85-97]

Rubén Darío ha bebido, viva Darío [3,114132]

Alrededor de César Vallejo. Poemas póstumos [4, 97-106]

La novela de la revolución mexicana en la narrativa hispanoamericana contemporánea $[5,123-136]$

Altazor, un poema creacionista de Vicente Huidobro [6/7, 145-154] 
TOVAR, Paco

TOVAR, Paco

y Maria Gabriella DIONISI

TRANCÓN LAGUNAS, Montserrat

TRAPIELLO, Andrés

TURIEL, Josep M.

VILA, $M^{\mathrm{a}}$ Nieves

VILLALBA, Juan Manuel

VISA, Miquel

VISA, Miquel

VICH FLÓREZ, Cynthia

WALTHAUS, Rina

YANKE, Germán

ZUBILLAGA, Carina
Algo más que una simple historia senil: "El Abuelo", de Mario Vargas Llosa [8/9, 129-133]

Introducción [21-22, 7-8]

“El puñal” de Augusto Ferrán [16, 47-56]

Divagaciones para un poeta moderno [10, 167-169]

La edición y el acceso a la literatura y los materiales GLTBQ [19/20, 257-280]

Mosén Jacinto y Mosén Millán. Papel de la Iglesia durante la guerra civil en la narrativa del exilio [4, 69-75]

Saber encontrar. El corazón azul del alumbrado, Benjamín Prado [10, 152-153]

Presentación [18, 7-8]

Las llaves de San Sebastián [18, 101-113]

Entrevista a Cristina Peri Rossi [8/9, 229237]

Espacio y alienación en Grimalte y Gradissa de Juan de Flores [13, 5-18]

La figuración irónica [10, 53-67]

Prácticas de lectura y escritura medieval en la compilación de las historias piadosas del Ms. Esc. h-i-13 [23/24/25, 177-194 ]. 


\section{III. Índice de materias}

1942. Vida y tiempos de Juan Cabezón de Castilla (Homero Aridjis) [8/9, 135-150] vid. Aridjis, Homero; vida

20 poemas para ser leídos en el tranvía (Oliverio Girondo) [6/7, 155-163]

vid. Girondo, Oliverio; poema

5 metros de poemas (Carlos Oquendo de Amat) [8/9, 255-265]

vid. poema; Oquendo de Amat, Carlos

8 poemas (Alfonso Costafreda) [1, 49-64]

vid. Costafreda, Alfonso; poema

¿A dónde irás ña Romualda? (Josefina Plá) [21/22, 191-200]

vid. Plá, Josefina

"A la memoria de mi Hermano" (Carmen Casartelli) [21/22, 125-138]

vid. Casartelli, Carmen; memoria

"A Roma sepultada en sus ruinas" (Francisco de Quevedo y Villegas) [11, 31-42]

vid. Quevedo y Villegas, Francisco de

Ab urbe condita (Tito Livio) [23/24/25, 213-233]

vid. Livio, Tito

abbreviatio [23/24/25, 11-41]

Abreu y Galindo, Juan de

Historia de la conquista de las siete islas Canarias

(Juan de Abreu y Galindo) [13, 151-171]

vid. historia

Acaso una verdad (Andrés Trapiello) [10, 164-166]

vid. Trapiello, Andrés

acceso a la información [19/20, 257-280]

vid. información

Acosta, Delfina

"La solterona" (Delfina Acosta) [21/22, 125-138]

acotaciones escénicas [17, 113-131] 
actor / actriz

actores del Siglo de Oro [17, 239-318]

actores del siglo XVII [17, 133-159]

actores del Siglo de Oro, apodos de [17, 239-318]

actrices del Siglo de Oro [17, 177-209]

admonición divina [23/24/25, 93-119]

Aforismos (Antonio Pérez) [11, 165-178]

vid. Pérez, Antonio

Africa (Francesco Petrarca) [23/24/25, 213-233]

vid. Petrarca, Francesco

Alberti, Rafael

"Oda a Platko" (Rafael Alberti) [4, 77-90] álbum

Álbum de Familia (Rosario Castellanos) [12, 77-89]

vid. Castellanos, Rosario

La noche junto al álbum (Álvaro García) [10, 120-121]

vid. García, Álvaro

alma, vigilia del [13, 285-314]

Alcides alegórico [17, 7-31]

vid. alegoría

Aldana, Francisco de

Aldana, Francisco de [4, 9-19], [6/7, 41-49]

"Carta para Arias Montano" (Francisco de Aldana) [3, 78-91]

vid. carta

alegoría

Alcides alegórico [17, 7-31]

alegoría ovidiana [13, 139-149]

vid. Ovidio Nasón, Publio

Allegoriae super Ovidii Metamorphosin (Adolfo d'Orleans) [13, 139-149]

vid. metamorfosis; Orleans, Adolfo d'

alegórico-moral, doctrina católica medieval [13, 139-149]

alegóricos, personajes dramáticos [17, 113-131]

vid. drama; personaje

Alemán, Mateo

Guzmán de Alfarache (Mateo Alemán) [6/7, 15-23]

Alexandre/Alejandro Magno

"El Alejandro recobrado" [23/24/25, 255-313] 
Facsímil del Ms. Plut.36sin.7 de la Biblioteca Medicea Laurenziana (Florencia) $[\mathbf{2 3 / 2 4 / 2 5}, 315-374]$

Libro de Alexandre [13, 227-251]

vid. libro

Vida de Alejandro Magno [23/24/25, 255-313]

vid. vida

Alexis o el tratado del inútil combate (Marguerite Yourcenar) [2, 5-9]

vid. Yourcenar, Marguerite

Alfonso X

Cantigas de Santa María (Alfonso X) [13, 101-113]

Estoria de Espanna (Alfonso X) [19/20, 21-35], [23/24/25, 155-176]

Partida Segunda (Alfonso X) [13, 101-113], [13, 115-137]

alienación [13, 5-18]

Allegoriae super Ovidii Metamorphosin (Adolfo d'Orleans) [13, 139-149]

vid. alegoría; metamorfosis; Orleans, Adolfo d'

Altamira, Rafael

Mi primera campaña (Rafael Altamira) [6/7, 91-104]

Altazor (Vicente Huidobro) [6/7, 145-154]

vid. Huidobro, Vicente

Althaus, Clemente [8/9, 53-72]

alto cómico / bajo cómico [15, 29-50]

vid. cómico

Amadís de Gaula (Garci Rodríguez de Montalvo) [13, 193-206], [19/20, 75-93]

vid. Rodríguez de Montalvo, Garci

anagnórisis [13, 43-57], [15, 121-131]

analfabetismo

analfabetismo [14, 73-78]

neoanalfabetos parciales [14, 73-78]

neoanalfabetos totales $[\mathbf{1 4}, 73-78]$

anarquista, literatura [6/7, 181-187]

vid. literatura

Andanças e viajes (Pero Tafur) [13, 179-191]

vid. Tafur, Pero; viaje

antifeminismo $[\mathbf{1 5}, 169-176]$

vid. feminismo

antigalleguismo en el Siglo de Oro [11, 203-246]

antología

antología medieval [23/24/25, 177-194] 
antologías medievales [23/24/25, 43-64]

antologías poéticas de posguerra [2, 29-37]

vid. poética; posguerra

apodos de actores del Siglo de Oro [17, 239-318]

vid. actor / actriz

Aquel viejo dolor (Teresa Lamas) [21/22, 79-96]

vid. Lamas, Teresa

“Aquella mora garrida" [13, 277-284]

Aragon, Louis [8/9, 239-248]

Arana, José Ramón

El cura de Almuniaced (José Ramón Arana) [4, 69-75]

Aridjis, Homero

1942. Vida y tiempos de Juan Cabezón de Castilla (Homero Aridjis) [8/9, 135-150] vid. vida

Aristóteles

Ética a Nicómaco (Aristóteles) [13, 33-42]

vid. ética

Poética (Aristóteles) [15, 11-27]

vid. poética

Ariza, Juan de

Cuentos de vieja (Juan de Ariza) [16, 25-46]

vid. cuento

artículo

artículo de costumbres [16, 89-101]

vid. Costumbrismo

artículos periodísticos (Rafael Barret): La tierra, La huelga, El problema sexual [21/22, 153-171]

vid. Barret, Rafael; sexualidad

Aselión, Sempronio

Res Gestae (Sempronio Aselión) [2, 111-115], [14, 11-16]

Asún, Raquel [6/7, 9-12]

vid. bibliografía

autobiografía

autobiografía [2, 39-49]

Autobiografía (Rubén Darío) [6/7, 115-122]

vid. Darío, Rubén

automatismo surrealista [18, 87-99]

vid. Surrealismo 
autos sacramentales [17, 33-46]

"Axí com cell qui.n lo somni.s delita" (Ausiàs March) [3, 24-47]

vid. March, Ausiàs

Ayala Cantero, María Eugenia

"De nuevo con los pies en el tablero" [21/22, 139-151]

Azuela, Mariano

Los de abajo [5, 123-136]

baile

El baile de Luis Alonso (Javier de Burgos y Gerónimo Giménez) [15, 77-88]

vid. Burgos, Javier de y Giménez, Gerónimo

Los Juan Ranas (baile) [17, 227-261]

Ballesteros, Rafael

Las contracifras (Rafael Ballesteros) [6/7, 215-221]

Bareiro Saguier, Rubén

Ojo por diente (Rubén Bareiro Saguier) [21/22, 259-273]

Barral, Carlos

"Prosa para un fin de capítulo" (Carlos Barral) [2, 51-61]

Barret, Rafael

Barret, Rafael [21/22, 215-246]

Lo que son los yerbales (Rafael Barret) [21/22, 153-171]

Artículos periodísticos (Rafael Barret): La tierra, La huelga, El problema sexual [21/22, 153-171]

vid. sexualidad

Bécquer, Gustavo Adolfo

Leyendas (Gustavo Adolfo Bécquer) [16, 47-56]

Beltenebros (Antonio Muñoz Molina) [6/7, 223-227]

vid. Muñoz Molina, Antonio

Benítez Reyes, Felipe

La mala compañia (Felipe Benítez Reyes) [10, 158-160]

Benjamin, Walter

Iluminaciones (Walter Benjamin) [14, 103-112]

Infancia en Berlín hacia 1900 (Walter Benjamin) [14, 103-112]

Bergson, Henri [18, 87-99]

Bernhard, Thomas

El Origen (Thomas Bernhard) [4, 91-95]

bibliografía

"Bibliografía de Raquel Asún" [6/7, 9-11]

bibliografía cubillesca [17, 89-112] 
(bibliografía) mujer en la literatura española [12, 185-214]

vid. literatura; mujer

(bibliografia) mujer en la literatura occidental [12, 215-252]

vid. literatura; mujer

bibliografía Primaleón [13, 173-178]

A Bibliography, Castilian Romances of a Chivalry in the Sixteenth Century:

(Daniel Eisenberg) [13, 173-178]

vid. caballería; Eisenberg, Daniel

biografía

biografía institucional [19/20, 201-218]

biografia literaria [19/20, 201-218]

biográfico medieval, relato [13, 227-251]

vid. relato

bipolaridad daliniana [18, 25-39]

vid. Dalí, Salvador

Blade Runner [14, 49-64]

Bocados de oro $[13,227-251]$

Boccaccio, Giovanni

Elegia di Madonna Fiammeta (Giovanni Boccaccio) [13, 5-18]

Genealogia deorum gentilium (Giovanni Boccaccio) [13, 19-31]

vid. genealogía

Boccaccio, prácticas traductológicas [23/24/25, 235-254]

vid. traducción

Bondía, Ambrosio

Cítara de Apolo y Parnaso en Aragón (Ambrosio Bondía) [11, 141-153]

Bremond, Henri

Histoire littéraire du sentiment religieux en France (Henri Bremond) [6/7, 25-40]

vid. historia; religión

Bryce Echenique, Alfredo

Un mundo para Julius (Alfredo Bryce Echenique) [8/9, 195-211]

Buñuel, Luis

Un perro andaluz (Luis Buñuel y Salvador Dalí) [18, 49-63]

Burgos, Javier de y Giménez, Gerónimo

El baile de Luis Alonso (Javier de Burgos y Gerónimo Giménez) [15, 77-88] vid. baile

caballería

caballeresca, literatura [13, 101-113]

vid. literatura 
caballerescos, compendios [13, 227-251]

vid. compendio

caballería, recepción de la $[\mathbf{1 3}, 101-113]$

caballerías, novela de [13, 193-206]

vid. novela

caballero Zifar, Libro del [13, 115-137]

vid. libro

caballeros hidalgos $[\mathbf{1 3}, 115-137]$

caballeros villanos [13, 115-137]

Castilian Romances of a Chivalry in the Sixteenth Century: A Bibliography

(Daniel Eisenberg) [13, 173-178]

vid. bibliografía; Eisenberg, Daniel

Doctrinal de Cavalleros (Alonso de Cartagena) [13, 101-113]

vid. Cartagena, Alonso de

Calcomanías (Oliverio Girondo) [6/7, 155-163]

vid. Girondo, Oliverio

Calderón de la Barca, Pedro

Calderón de la Barca, Pedro [6/7, 51-56]

El golfo de las sirenas (Pedro Calderón de la Barca) [17, 227-261]

El gran teatro del mundo (Pedro Calderón de la Barca) [2, 99-109]

El príncipe constante (Pedro Calderón de la Barca) [11, 179-189]

Juan Rana en la Zarzuela (Pedro Calderón de la Barca) [17, 227-261]

La aurora en Copacabana (Pedro Calderón de la Barca) [17, 33-46]

La vida es sueño (Pedro Calderón de la Barca) [17, 47-63]

Polonia calderoniana [17, 47-63]

Campillo y Correa, Narciso

Una docena de cuentos (Narciso Campillo y Correa) [16, 133-142]

vid. cuento

Campos Cervera, Hérib [21/22, 111-123]

Canals, Antoni

Scipió e Anibal (Antoni Canals) [23/24/25, 213-233]

cancionero

Cancionero de obras de burlas provocantes a risa [19/20, 37-56]

vid. risa

Cancionero musical de Palacio [13, 277-284]

Cansonero del Conde de Popoli [23/24/25, 195-211]

Cantigas de Santa María (Alfonso X) [13, 101-113]

vid. Alfonso X 
Canto a su amor desaparecido (Raúl Zurita) [8/9, 283-290]

vid. Zurita, Raúl

"Canto Libertario" (Elsa Wiezell) [21/22, 125-138]

vid. Wiezell, Elsa

Cañizares, José

El asombro de Jerez, Juana la Rabicortona (José Cañizares) [15, 121-131]

Carajicomedia [19/20, 37-56]

vid. comedia

carcajada romántica $[\mathbf{1 5}, 99-120]$

vid. risa; Romanticismo

Cárcel de Amor (Diego de San Pedro) [13, 193-206]

vid. San Pedro, Diego de

Carmagnola, Gladys

"Destiempo" (Gladys Carmagnola) [21/22, 125-138]

Carner, Josep [12, 101-128]

Carpe noctem (Aurora Luque) $[\mathbf{1 0}, 122]$

vid. Luque, Aurora

Carpentier, Alejo

La consagración de la primavera (Alejo Carpentier) [2, 85-97]

Carrillo de Acuña, Alfonso [13, 67-99]

Cartagena, Alonso de

Doctrinal de Cavalleros (Alonso de Cartagena) [13, 101-113]

vid. caballería

carta

"Carta para Arias Montano" (Francisco de Aldana) [3, 78-91]

vid. Aldana, Francisco de

Carta que embio un religioso al señor Arçobispo de Toledo [13, 67-99]

Cartas de amor a Margarita, 1912-1915 (Pedro Salinas) [6/7, 13-14]

vid. Salinas, Pedro

cartas de desafío [13, 67-99]

Cartas en refranes (Blasco de Garay) [13, 217-226]

vid. Garay, Blasco de; refrán

Cartas españolas (Antonio Pérez) [11, 165-178]

vid. Pérez, Antonio

Casa invadida (Antonio Jiménez Millán) [10, 146-148]

vid. Jiménez Millán, Antonio

Casaccia, Gabriel

La Babosa (Gabriel Casaccia) [21/22, 51-59], [21/22, 201-214] 
Casartelli, Carmen

"A la memoria de mi Hermano" (Carmen Casartelli) [21/22, 125-138]

Castellanos, Rosario

Álbum de Familia (Rosario Castellanos) [12, 77-89]

vid. álbum

Castilian Romances of a Chivalry in the Sixteenth Century: A Bibliography (Daniel Eisenberg) [13, 173-178]

vid. bibliografía; caballería; Eisenberg, Daniel

Castro Quesada, Américo [19/20, 9-20]

catacresis $[\mathbf{1 4}, 113-125]$

Catálogo (Fernando de Colón) [13, 173-178]

vid. Colón, Fernando de

catarsis cómica en el teatro [15, 11-27]

vid. cómico

causas y reglas de la risa [15, 11-27]

vid. risa

Centurión, Juan Crisóstomo

Viaje nocturno (Juan Crisóstomo Centurión) [21/22, 79-96]

vid. viaje

Cepeda y Ahumada, Teresa (Teresa de Jesús)

Libro de la Vida (Teresa de Jesús) [19/20, 57-73]

vid. libro; vida

Cervantes Saavedra, Miguel de

Cervantes Saavedra, Miguel de [19/20, 75-93]

Don Quijote de la Mancha (Miguel de Cervantes Saavedra) [6/7, 15-23]

El celoso extremeño (Miguel de Cervantes Saavedra) [11, 113-124]

El viejo celoso (Miguel de Cervantes Saavedra) [11, 113-124]

Los trabajos de Persiles y Sigismunda (Miguel de Cervantes Saavedra) [11, 83-91]

Chicharro, Eduardo

Chicharro, Eduardo [1, 37-47]

Los jeroglificos del caballo (Eduardo Chicharro) [2, 63-73]

Cicerón, Marco Tulio [15, 11-27]

Cielo rasante (Francisco Fortuny de los Ríos) [10, 140-143]

vid. Fortuny de los Ríos, Francisco

Cien años de soledad (Gabriel García Márquez) [8/9, 189-194]

vid. García Márquez, Gabriel

"Ciertas tardes" (María Eugenia Garay) [21/22, 139-151]

vid. Garay, María Eugenia 
Cirlot, Juan Eduardo

La Quête de Bronwyn (Juan Eduardo Cirlot) [5, 65-80]

Cítara de Apolo y Parnaso en Aragón (Ambrosio Bondía) [11, 141-153]

vid. Bondía, Ambrosio

ciudad

ciudad, poesía, poeta y [14, 103-112]

vid. poesía

ciudad y poesía española actual $[\mathbf{1 0}, 75-91]$

vid. poesía

ciudades Medina y Molina [13, 59-65]

"Clarín" (Leopoldo Alas)

La Regenta (Leopoldo Alas “Clarín”) [1, 5-13], [3, 105-113], [6/7, 83-90]

Su único hijo (Leopoldo Alas "Clarín”) [1, 15-23], [6/7, 83-90]

Colman Gutiérrez, Andrés

El último vuelo del pájaro campana (Andrés Colman Gutiérrez) [21/22, 97109]

Colón, Cristóbal

Colón, Cristóbal [8/9, 9-15]

Primer viaje (Cristóbal Colón) [13, 179-191]

vid. viaje

Colón, Fernando de

Catálogo (Fernando de Colón) [13, 173-178]

colonial hispanoamericana, literatura [8/9, 27-35]

vid. literatura

Colonne, Guido delle

Historia Destructionis Troiae (Guido delle Colonne)

[23/24/25, 65-91], [23/24/25, 155-176]

vid. historia; Troya

comedia

Carajicomedia [19/20, 37-56]

Comedia Armelina (Lope de Rueda) [17, 211-225]

vid. Rueda, Lope de

comedia de capa y espada [15, 121-131], [17, 89-112]

comedia de figurón [17, 89-112]

comedia de magia $[\mathbf{1 5}, 121-131]$

comedia de santos [6/7, 51-56]

comedia erudita italiana del siglo XVI $[\mathbf{1 7}, 161-176]$ 
comedia neoclásica española [19/20, 95-100]

comedia seria [15, 133-144]

comedia y autor cómico [15, 11-27]

vid. cómico

comedia, parodia y [15, 89-98]

vid. parodia

comedias de costumbres [17, 89-112]

vid. Costumbrismo

comedias de historia y leyenda [17, 89-112]

vid. historia; leyenda

comedias religiosas [17, 89-112]

vid. religión

comedias, censura de [17, 65-87]

comedias, prohibiciones de [17, 65-87]

Commedia dell'arte [17, 161-176]

commedia ridiculosa $[\mathbf{1 7}, 161-176]$

Comella, Luciano Francisco

La Cecilia (Luciano Francisco Comella) [15, 133-144]

comicidad [3, 58-76]

cómico

cómica, catarsis en el teatro [15, 11-27]

cómico, alto / cómico, bajo [15, 29-50]

cómico, comedia y autor $[\mathbf{1 5}, 11-27]$

vid. comedia

cómico, contrapunto [15, 145-158]

cómico, personaje [15, 145-158]

vid. personaje

cómico, teatro breve $[\mathbf{1 5}, 51-75]$

vid. teatro

cómico, teatro breve español del Siglo de Oro [17, 227-261]

vid. teatro

cómicos, relatos [16, 133-142]

vid. relato

Compañera de hoy (Alfonso Costafreda) [2, 11-27]

vid. Costafreda, Alfonso

Company, Flavia

Melalcor (Flavia Company) [19/20, 219-237] 
compendio

compendio de castigos [13, 227-251]

compendios caballerescos [13, 227-251]

vid. caballería

competencia comunicativa [14, 93-102]

compilatio

compilaciones troyanas $[\mathbf{2 3 / 2 4 / 2 5}, 155-176]$

vid. Troya

compilatio [23/24/25, 155-176], [23/24/25, 177-194]

compilatio, translatio et [23/24/25, 11-41]

vid. translatio

Contraataque (Ramón J. Sender) [5, 51-64]

vid. Sender, Ramón J.

contrapunto cómico $[\mathbf{1 5}, 145-158]$

vid. cómico

conversación

conversaciones artísticas [18, 13-23]

conversaciones directas / indirectas [18, 13-23]

conversaciones epistolares [18, 13-23]

vid. epístola

copla

copla española [19/20, 187-199]

Coplas de don Jorge Manrique por la muerte de su padre [13, 285-314]

Coplas de Fernando de la Vera [13, 151-171]

Coplas de Mingo Revulgo [13, 151-171]

Coplas del tabefe [13, 151-171]

"Corazón bleu y coeur azul" (Federico García Lorca) [18, 13-23]

vid. García Lorca, Federico

Córdoba, Alfonso de

Epistola et regimen de pestilentia (Alfonso de Córdoba) [13, 253-275]

vid. epístola

Cortázar, Julio

Rayuela (Julio Cortázar) [1, 77-89]

cosmovisión romántica [16, 57-87]

vid. Romanticismo

Costafreda, Alfonso

Compañera de hoy (Alfonso Costafreda) [1, 49-64], [2, 11-27]

Nuestra elegía (Alfonso Costafreda) [1, 49-64] 
8 poemas (Alfonso Costafreda) [1, 49-64]

vid. poema

Suicidios y otras muertes (Alfonso Costafreda) [1, 49-64]

Costumbrismo

costumbres, artículo de [16, 89-101]

vid. artículo

costumbres, comedias de [17, 89-112]

vid. comedia

costumbres, cuadro de [16, 89-101], [16, 103-118]

vid. cuadro

costumbrista, cuento $[\mathbf{1 6}, 25-46],[\mathbf{1 6}, 171-187]$

vid. cuento

costumbrista, risa $[\mathbf{1 5}, 99-120]$

vid. risa

cotidie morimur [11, 247-256]

Cristianismo

cristianismo y paganismo $[\mathbf{1 3}, 33-42]$

Cristianos y moriscos (Serafín Estébanez Calderón) [6/7, 57-63]

vid. Estébanez Calderón, Serafín

cristianos y moros [13, 59-65]

crítica

crítica calderoniana del siglo XVII [17, 279-292]

crítica como sabotaje [19/20, 111-139]

crítica y caricatura [16, 119-132]

crítico medieval española, literatura de alegato $[\mathbf{1 3}, 151-171]$

vid. literatura

paranoico-crítico, método [18, 87-99], [18, 101-113]

crónica

Corónica de los conquiridores (Juan Fernández de Heredia) [23/24/25, 11-41]

vid. Fernández de Heredia, Juan

Crónica (Diego Enríquez del Castillo) [13, 67-99]

vid. Enríquez del Castillo, Diego

Crónica Troyana (Juan Fernández de Heredia) [23/24/25, 65-91]

vid. Fernández de Heredia, Juan; Troya

Grant Crónica d'Espanya (Juan Fernández de Heredia) [23/24/25, 155-176]

vid. Fernández de Heredia, Juan

Nueva crónica y buen gobierno (Felipe Guaman Poma de Ayala) [11, 191-201] vid. Guaman Poma de Ayala, Felipe 
cuadro

cuadro de costumbres [16, 89-101], [16, 103-118]

vid. Costumbrismo

"cuadros" dramáticos del Siglo de Oro [17, 33-46]

vid. drama

"El cuadro de maese Abraham. Cuento" (Pedro Escamilla) [16, 103-118]

vid. cuadro; cuento; Escamilla, Pedro

Cubillo de Aragón, Álvaro

El Señor de Buenas Noches (Álvaro Cubillo de Aragón) [17, 89-112]

Las muñecas de Marcela (Álvaro Cubillo de Aragón) [17, 89-112]

Cruz Cano y Olmedilla, Ramón de la

Los bandos del Avapiés (Ramón de la Cruz Cano y Olmedilla) [15, 51-75] cuento

cuento costumbrista $[\mathbf{1 6}, 25-46],[16,171-187]$

vid. Costumbrismo

cuento "estrambótico" [16, 57-87]

cuento histórico [16, 9-23]

vid. historia

cuento humorístico [16, 149-156]

cuento romántico español en verso [16, 9-23]

vid. Romanticismo

cuentos $[\mathbf{1 6}, 157-170]$

Cuentos (José Fernández Bremón) [16, 119-132]

vid. Fernández Bremón, José

Cuentos de vieja (Juan de Ariza) [16, 25-46]

vid. Ariza, Juan de

cuentos folclóricos españoles [16, 25-46]

cuentos humorísticos [16, 133-142]

cuentos populares [16, 133-142]

cuentos realistas-naturalistas [16, 171-187]

vid. Naturalismo; Realismo

cuento, género [16, 133-142], [16, 171-187]

vid. género

cuento en el siglo XIX, género [16, 89-101]

vid. género

"El cuadro de maese Abraham. Cuento" (Pedro Escamilla) [16, 103-118]

vid. cuadro; Escamilla, Pedro 
"El espejo. Cuento" (Pedro Escamilla) [16, 103-118] vid. Escamilla, Pedro

El salvador (cuentos varios) (Blanca de los Ríos) [16, 171-187] vid. Ríos, Blanca de los

La rondeña (cuentos andaluces) (Blanca de los Ríos) [16, 171-187] vid. Ríos, Blanca de los

La Seca y otros cuentos (Renée Ferrer) [21/22, 275-290] vid. Ferrer, Renée

Las Madres. Cuentos de Salón (Carlos Frontaura) [16, 89-101] vid. Frontaura, Carlos

Una docena de cuentos (Narciso Campillo y Correa) [16, 133-142] vid. Campillo y Correa, Narciso

cuerpo

сиегро $[\mathbf{1 9 / 2 0}, 219-237]$

cuerpo, sujeto y $[\mathbf{1 9 / 2 0}, 57-73]$

cultura

cultura americana [19/20, 201-218]

cultura greco-latina [23/24/25, 121-153]

cultura popular [19/20, 187-199]

Dalí, Salvador

Dalí, Salvador [18, 25-39], [18, 81-85]

bipolaridad daliniana [18, 25-39]

El gran Masturbador (Salvador Dalí) [18, 49-63], [18, 41-47]

histrionismo de Dali [18, 75-79] vid. histrión

La femme visible (Salvador Dalí) [18, 87-99]

La Metamorfosis de Narciso (Salvador Dalí) [18, 41-47] vid. metamorfosis

Los Putrefactos (Federico García Lorca y Salvador Dalí) [18, 13-23] vid. García Lorca, Federico

mito Dali $[18,25-39]$ vid. mito

“Oda a Salvador Dalí" (García Lorca, Federico) [18, 101-113] vid. García Lorca, Federico

personaje Dali $[\mathbf{1 8}, 65-69]$

vid. personaje

"Pez perseguido por una uva" (Salvador Dalí) [18, 13-23] 
poesía de Salvador Dalí [18, 87-99]

vid. poesía

"Sant Sebastià" (Salvador Dalí) [18, 101-113]

Tardes d'estiu (Salvador Dalí) [18, 65-69]

Un perro andaluz (Luis Buñuel y Salvador Dalí) [18, 49-63]

vid. Buñuel, Luis

Vida secreta de Salvador Dalí (Salvador Dalí) [18, 41-47], [18, 65-69] vid. vida

Dalton, Roque

Pobrecito poeta que era yo... (Roque Dalton) [8/9, 291-296]

danza $[\mathbf{1 5}, 77-88]$

Darío, Rubén

Darío, Rubén [3, 114-132]

Historia de mis libros (Rubén Darío) [6/7, 115-122]

vid. historia; libro

Autobiografía (Rubén Darío) [6/7, 115-122]

vid. autobiografía

De mar a mar (1942-1943) [8/9, 341-357]

"De senectute" (Jaime Gil de Biedma) [5, 81-87]

vid. Gil de Biedma, Jaime

De sobremesa (José Asunción Silva) [8/9, 83-97]

vid. Silva, José Asunción

debate sociológico [14, 113-125]

"Decepción" (Dora Gómez Bueno de Acuña) [21/22, 139-151]

vid. Gómez Bueno de Acuña, Dora

declamación

declamación a la francesa $[\mathbf{1 5}, 29-50]$

declamación histriónica [15, 29-50]

vid. histrión

Delgado, Susy [21/22, 125-138]

Delibes, Miguel

Los Santos Inocentes (Miguel Delibes) [5, 89-98]

Deniz, Gerardo [8/9, 335-340]

derecho a la información [19/20, 257-280]

vid. información

desamor [12, 173-184]

Descartes, René

Discours de la Méthode (René Descartes) [14, 31-45] 
vid. discurso

Méditations (René Descartes) [14, 17-30]

Principia Philosophae (René Descartes) [14, 31-45]

vid. filosofía

descriptio, narratio y catalogus [13, 179-191]

deseo [21/22, 201-214]

"Destiempo" (Gladys Carmagnola) [21/22, 125-138]

vid. Carmagnola, Gladys

diálogo

dialogada, poesía [13, 33-42]

vid. poesía

diálogo y anécdota $[\mathbf{1 4}, 65-71]$

diálogo figurativo [18, 13-23]

diálogos platónicos [14, 31-45]

vid. Platón

Díaz del Castillo, Bernal

Historia verdadera de la conquista de la Nueva España

(Bernal Díaz del Castillo) [8/9, 17-26]

vid. historia

Díaz de Games, Gutierre [13, 227-251]

El Victorial (Gutierre Díaz de Games) [13, 227-251]

diégesis [17, 211-225]

Diego Padró, José I. de [19/20, 163-185]

Diez qüestiones vulgares (Alfonso de Madrigal "el Tostado") [13, 19-31], [13, 139-149]

vid. Madrigal "el Tostado", Alfonso de

discurso

Discours de la Méthode (René Descartes) [14, 31-45]

vid. (Descartes, René)

discurso epidíctico [13, 67-99]

discurso histórico y ficción [21/22, 215-246]

vid. ficción; historia

discursos historiográficos [23/24/25, 43-64]

vid. historiografía

doctrina alegórico-moral católica medieval [13, 139-149]

vid. alegoría

Doctrinal de Cavalleros (Alonso de Cartagena) [13, 101-113]

vid. caballería; Cartagena, Alonso de 
dominación masculina [21/22, 191-200]

Don Juan Tenorio (José Zorrilla) [6/7, 65-71], [15, 99-120] vid. Zorrilla, José

Don Quijote de la Mancha (Miguel de Cervantes Saavedra) [6/7, 15-23] vid. Cervantes Saavedra, Miguel de

Donoso, María Pilar

Los de entonces (Recuerdos) (María Pilar Donoso) [8/9, 111-118]

D’Ors, Eugeni [12, 101-128]

"Dos palabras a mi sexo" (Casta Esteban y Navarro) [14, 65-71] vid. Esteban y Navarro, Casta; sexualidad

drama

Drama de familia (Jacinto Octavio, Picón) [16, 157-170]

vid. Picón, Jacinto Octavio

drama y melodrama [15, 177-189]

dramática, mojiganga [17, 227-261]

vid. mojiganga

dramático culterano, estilo [17, 7-31]

dramático, construcción del personaje [17, 113-131]

vid. personaje

dramáticos alegóricos, personajes [17, 113-131]

vid. alegoría; personaje

dramáticos breves, géneros [15, 77-88]

vid. género

dramáticos del Siglo de Oro, "cuadros" [17, 33-46]

vid. cuadro

dramáticos históricos, personajes [17, 113-131]

vid. historia; personaje

dramáticos pastoriles, personajes [17, 113-131]

vid. personaje

Drop a Star (León Felipe) [1, 25-35]

vid. Felipe, León

Duarte, Ciriaco [21/22, 153-171]

ecdótica [23/24/25, 11-41]

Ecos de monte y de arena (Luisa Moreno) [21/22, 61-78]

vid. Moreno, Luisa

edición y distribución [19/20, 257-280]

Egea, Javier

Paseo de los tristes (Javier Egea) [10, 170-173] 
Égloga de la Natividad (Hernán López de Yanguas) [17, 113-131]

vid. López de Yanguas, Hernán

Eisenberg, Daniel

Castilian Romances of a Chivalry in the Sixteenth Century: A Bibliography

(Daniel Eisenberg) [13, 173-178]

vid. bibliografía; caballería

"El abuelo" (Mario Vargas Llosa) [8/9, 129-133]

vid. Vargas Llosa, Mario

El acantilado del mar (Renée Ferrer) [21/22, 309-317]

vid. Ferrer, Renée

El águila y la serpiente (Martín Luis Guzmán) [5, 123-136]

vid. Guzmán, Luis Martín

"El Alejandro recobrado" [23/24/25, 255-313]

vid. Alexandre

El amigo imaginario (José Antonio Mesa Toré) [10, 144-145]

vid. Mesa Toré, José Antonio

El Anticristo (Juan Ruiz de Alarcón) [11, 93-112]

vid. Ruiz de Alarcón, Juan

El asombro de Jerez, Juana la Rabicortona (José Cañizares) [15, 121-131]

vid. Cañizares, José

El baile de Luis Alonso (Javier de Burgos y Gerónimo Giménez) [15, 77-88]

vid. baile; Burgos, Javier de y Giménez, Gerónimo

El buen discípulo (José Luis Piquero) $[\mathbf{1 0}, 115]$

vid. Piquero, José Luis

El burlador de Sevilla (Tirso de Molina) [15, 99-120], [17, 263-277]

vid. Tirso de Molina (fray Gabriel Téllez)

El castigo del penséque (Tirso de Molina) [11, 43-62]

vid. Tirso de Molina (fray Gabriel Téllez)

El celoso extremeño (Miguel de Cervantes Saavedra) [11, 113-124]

vid. Cervantes Saavedra, Miguel de

El celoso prudente (Tirso de Molina) [11, 43-62]

vid. Tirso de Molina (fray Gabriel Téllez)

El conde Dirlos [13, 43-57]

El contrabandista (Tomás Rodríguez Rubí y Basilio Basili) [15, 77-88]

vid. Rodríguez Rubí, Tomás y Basili, Basilio

El corazón azul del alumbrado (Benjamín Prado) [10,152-153]

vid. Prado, Benjamín 
El Criticón (Baltasar Gracián) [6/7, 15-23]

vid. Gracián, Baltasar

"El cuadro de maese Abraham. Cuento" (Pedro Escamilla) [16, 103-118]

vid. cuadro; cuento; Escamilla, Pedro

El cura de Almuniaced (José Ramón Arana) [4, 69-75]

vid. Arana, José Ramón

El diablo mundo (José de Espronceda) [16, 57-87]

vid. Espronceda, José de

El doctor Lañuela (Antonio Ros de Olano) [16, 57-87]

vid. Ros de Olano, Antonio

"El espejo. Cuento" (Pedro Escamilla) [16, 103-118]

vid. cuento; Escamilla, Pedro

El gran Masturbador (Dalí, Salvador) [18, 49-63], [18, 41-47]

vid. Dalí, Salvador

El golfo de las sirenas (Pedro Calderón de la Barca) [17, 227-261]

vid. Calderón de la Barca, Pedro

El gran teatro del mundo (Pedro Calderón de la Barca) [2, 99-109]

vid. Calderón de la Barca, Pedro

El mono gramático (Octavio Paz) [14, 93-102]

vid. Paz, Octavio

"El oficio de difuntos. Aventura extraordinaria" (Pedro Escamilla) [16, 103-118] vid. Escamilla, Pedro

El Origen (Thomas Bernhard) [4, 91-95]

vid. Bernhard, Thomas

El paisaje infinito (Juan Lamillar) [10, 161-163]

vid. Lamillar, Juan

El peluquero francés (Guido Rodríguez Alcalá) [21/22, 291-308]

vid. Rodríguez Alcalá, Guido

El Periódico para todos (1880-1883) [16, 103-118]

El Pompeyo (Cristóbal de Mesa) [17, 319-333]

vid. Mesa, Cristóbal de

El precio de los sueños (Josefina Plá) [21/22, 173-190]

vid. Plá, Josefina; sueño

El Príncipe Constante (Pedro Calderón de la Barca) [11, 179-189]

vid. Calderón de la Barca, Pedro

"El puñal” (Augusto Ferrán) [16, 47-56]

vid. Ferrán, Augusto

El resplandor (Mauricio Magdaleno) [5, 123-136] 
vid. Magdaleno, Mauricio

El resplandor y las sombras (Renée Ferrer) [21/22, 309-317]

vid. Ferrer, Renée

El retrato de Juan Rana (Sebastián de Villaviciosa) [17, 227-261]

vid. Villaviciosa, Sebastián de

El salvador (cuentos varios) (Blanca de los Ríos) [16, 171-187]

vid. cuento; Ríos, Blanca de los

El Señor de Buenas Noches (Álvaro Cubillo de Aragón) [17, 89-112]

vid. Cubillo de Aragón, Álvaro

El sí de las niñas (Leandro Fernández de Moratín) [15, 145-158]

vid. Fernández de Moratín, Leandro

El Tonel de Cerveza (José Fernández Bremón) [16, 119-132]

vid. Fernández Bremón, José

El último de la fiesta (Carlos Marzal) [10, 154-157]

vid. Marzal, Carlos

El último vuelo del pájaro campana (Andrés Colman Gutiérrez) [21/22, 97-109]

vid. Colman Gutiérrez, Andrés

El vergonzoso en palacio (Tirso de Molina) [11, 43-62]

vid. Tirso de Molina (fray Gabriel Téllez)

El Victorial (Gutierre Díaz de Games) [13, 227-251]

vid. Díaz de Games, Gutierre

El viejo celoso (Miguel de Cervantes Saavedra) [11, 113-124]

vid. Cervantes Saavedra, Miguel de

Elegia di Madonna Fiammeta (Giovanni Boccaccio) [13, 5-18]

vid. Boccaccio, Giovanni

élites latinoamericanas [19/20, 201-218]

Elittis, Odisseas [4, 5-8]

Embajada a Tamorlán (Ruy González de Clavijo) [13, 179-191]

vid. González de Clavijo, Ruy

Emilio Prados: la memoria del olvido (Patricio Hernández) [5, 37-41]

vid. Hernández, Patricio; memoria

Encina, Juan del

Tribagia (Juan del Encina) [13, 179-191]

Eneida (Publio Virgilio Marón) [17, 263-277]

vid. Virgilio Marón, Publio

enfermedad [19/20, 141-161]

Enríquez de la Ribera, Fadrique

Viaje de Jerusalén (Fadrique Enríquez de la Ribera) [13, 179-191] 
vid. viaje

Enríquez del Castillo, Diego

Crónica (Diego Enríquez del Castillo) [13, 67-99]

vid. crónica

ensayo

ensayístico, género [14, 31-45]

vid. género

ensayo post-moderno [14, 17-30]

Ensayo sobre la ceguera (José Saramago) [14, 113-125]

vid. Saramago, José

ensayo y filosofía [14, 17-30]

vid. filosofía

"ensayo", género [14, 7-8]

vid. género

Ensayos Completos (Pedro Salinas) [14, 73-78]

vid. Salinas, Pedro

Essais (Michel de Montaigne) [14, 17-30]

vid. Montaigne, Michel de

Mi primer ensayo (Casta Esteban y Navarro) [14, 65-71]

vid. Esteban y Navarro, Casta

entremés [17, 227-261]

epístola

Epistola et regimen de pestilentia (Alfonso de Córdoba) [13, 253-275]

vid. Códoba, Alfonso de

Epistolae (Coluccio Salutati) [13, 19-31]

vid. Salutati, Coluccio

epistolares, conversación [18, 13-23]

vid. conversación

“Epitaphium Rzymowi” (Mikolaj Sep Szarzynski) [11, 31-42]

vid. Sep Szarzynski, Mikolaj

erótico

erótica femenina, poesía [21/22, 139-151]

vid. poesía

erótico, género gramatical y género [19/20, 187-199]

vid. erotismo; género

erotismo

erotismo [19/20, 57-73], [19/20, 141-161], [21/22, 173-190]

erotismo femenino [21/22, 125-138], [19/20, 163-185], [21/22, 139-151] 
erotismo intercultural $[\mathbf{1 3}, 277-284]$

erotismo y modernidad [19/20, 95-100]

homoerotismo [19/20, 187-199]

Escamilla, Pedro

"El cuadro de maese Abraham. Cuento" (Pedro Escamilla) [16, 103-118] vid. cuadro; cuento

"El espejo. Cuento" (Pedro Escamilla) [16, 103-118] vid. cuento

"El oficio de difuntos. Aventura extraordinaria" (Pedro Escamilla) [16, 103118]

Escenas andaluzas (Serafín Estébanez Calderón) [6/7, 57-63]

vid. Estébanez Calderón, Serafín

escepticismo [14, 113-125]

escritura

escritura automática [18, 87-99]

escritura filosófica [14, 31-45]

vid. filosofía

escritura y oralidad [21/22, 9-32]

vid. oralidad

"escuderos fijosdalgo" [13, 115-137]

escuela

escuela de Calderón [17, 89-112]

escuela de Lope [17, 89-112]

espacio itinerante [13, 5-18]

espectáculo de festejos [17, 7-31]

Espejos (Abelardo Linares) [10, 132-134]

vid. Linares, Abelardo

Espínola, Lourdes

"Nacer Mujer-Poeta" (Lourdes Espínola) [21/22, 125-138]

vid. mujer; poeta

espíritu fáustico [14, 49-64]

Espronceda, José de

El diablo mundo (José de Espronceda) [16, 57-87]

Esquilo

Prometeo Encadenado (Esquilo) [14, 49-64]

vid. Prometeo

Essais (Michel de Montaigne) [14, 17-30]

vid. ensayo; Montaigne, Michel de 
Esteban y Navarro, Casta

"Dos palabras a mi sexo" (Casta Esteban y Navarro) [14, 65-71] vid. sexualidad

“Existe el amor?” (Casta Esteban y Navarro) [14, 65-71]

Mi primer ensayo (Casta Esteban y Navarro) [14, 65-71]

vid. ensayo

Estébanez Calderón, Serafín

Escenas andaluzas (Serafín Estébanez Calderón) [6/7, 57-63]

Cristianos y moriscos (Serafín Estébanez Calderón) [6/7, 57-63]

vid. Cristianismo

estética

estética de la objetividad [18, 101-113]

estética y teoría literaria [18,9-11]

estética, experiencia [18, 9-11]

estética, filosofía y [14, 7-8]

vid. filosofía

estéticos, temas [18, 13-23]

vid. temas

estilo dramático culterano [17, 7-31]

vid. drama

Esto es andar (Ida Talavera de Fracchia) [21/22, 139-151]

vid. Talavera de Fracchia, Ida

Estoria de Espanna [19/20, 21-35], [23/24/25, 155-176]

vid. Alfonso X; historia

ética

Ética a Nicómaco (Aristóteles) [13, 33-42]

vid. Aristóteles

ética, literatura y [14, 7-8]

vid. literatura

etimología [13, 217-226]

Eufemia (Lope de Rueda) [17, 211-225]

vid. Rueda, Lope de

evocación española en Le Bossu (Paul Féval) [15, 177-189]

vid. Féval, Paul; Le Bossu

exaltación del presente [14, 127-128]

Examen de ingenios para las ciencias (Juan Huarte de San Juan) [6/7, 15-23]

vid. Huarte de San Juan, Juan 
exclamatio [13, 67-99]

exempla [13, 179-191], [14, 65-71], [23/24/25, 235-254]

exilio, literatura española del [8/9, 335-340], [8/9,359-368]

vid. literatura

“Existe el amor?” (Casta Esteban y Navarro) [14, 65-71]

vid. Esteban y Navarro, Casta

experiencia estética $[\mathbf{1 8}, 9-11]$

vid. estética

fábulas antiguas [13, 139-149]

Facsímil del Ms. Plut.36sin.7 de la Biblioteca Medicea Laurenziana (Florencia)

[23/24/25, 315-374]

farsa

Farsa del Mundo y Moral (Hernán López de Yanguas) [17, 113-131]

vid. López de Yanguas, Hernán

Farsa Turquesana (Hernán López de Yanguas) [17, 113-131]

vid. López de Yanguas, Hernán

farsas de comediantes [17, 65-87]

Farsalia (Marco Anneo Lucano) [17, 319-333]

vid. Lucano, Marco Anneo

Fausto (Goethe) [14, 49-64]

Federico García Lorca: heterodoxo y mártir (Eutimio Martín) [4, 113-120]

vid. García Lorca, Federico; Martín, Eutimio

Felipe, León

Versos y oraciones del caminante (León Felipe) [1, 25-35]

Drop a Star (León Felipe) [1, 25-35]

Ganarás la luz (León Felipe) [6/7, 197-203]

feminismo

antifeminismo [15, 169-176]

feminismo europeo a finales del siglo XIX [14, 65-71]

Fernández Bremón, José

Cuentos (José Fernández Bremón) [16, 119-132]

vid. cuento

El Tonel de Cerveza (José Fernández Bremón) [16, 119-132]

Un crimen científico (José Fernández Bremón) [16, 119-132]

Fernández de Avellaneda, Alonso

Quijote de Avellaneda (Alonso Fernández de Avellaneda) [19/20, 75-93] vid. Quijote 
Fernández de Heredia, Juan

Fernández de Heredia, Juan [23/24/25, 11-41], [23/24/25, 121-153], [23/24/25, 93-119], [23/24/25, 43-64], [23/24/25, 65-91]

Corónica de los conquiridores (Juan Fernández de Heredia) [23/24/25, 11-41] vid. crónica

Crónica Troyana (Juan Fernández de Heredia) [23/24/25, 65-91]

vid. crónica; Troya

Flor de las ystorias de Orient (Juan Fernández de Heredia) [23/24/25, 11-41],

[23/24/25, 93-119]

vid. historia

Grant Crónica d'Espanya (Juan Fernández de Heredia) [23/24/25, 155-176]

vid. crónica

Vidas de hombres ilustres (Juan Fernández de Heredia) [23/24/25, 121-153]

vid. vida

Fernández de Moratín, Leandro

El sí de las niñas (Leandro Fernández de Moratín) [15, 145-158]

Fernández de Moratín, Nicolás [19/20, 95-100]

Fernández Granell, Eugenio

La novela del Indio Tupinamba (Eugenio Fernández Granell) [4, 55-68]

vid. novela

Fernández, Heriberto

Juventud (Heriberto Fernández) [21/22, 111-123]

Ferrán, Augusto

"El puñal" (Augusto Ferrán) [16, 47-56]

Ferrater, Gabriel [6/7, 205-213]

Ferrer, Renée

Ferrer, Renée [21/22, 125-138], [21/22, 275-290], [21/22, 309-317]

Desde el encendido corazón del monte (Renée Ferrer) [21/22, 61-78]

"Estaciones III" (Renée Ferrer) [21/22, 139-151]

"Gestación" (Renée Ferrer) [21/22, 139-151]

"La exposición" (Renée Ferrer) [21/22, 275-290]

Los nudos del silencio (Renée Ferrer) [21/22, 275-290]

vid. silencio

La Seca y otros cuentos (Renée Ferrer) [21/22, 275-290]

vid. cuento

La Querida (Renée Ferrer) [21/22, 291-308]

El acantilado del mar (Renée Ferrer) [21/22, 309-317]

El resplandor y las sombras (Renée Ferrer) [21/22, 309-317] 
Peregrino de la eternidad (Renée Ferrer) [21/22, 309-317]

Sobreviviente (Renée Ferrer) [21/22, 309-317]

Féval, Paul

evocación española en Le Bossu (Paul Féval) [15, 177-189]

Le Bossu (Paul Féval) [15, 177-189]

ficción

ficción [23/24/25, 65-91]

ficción literaria, historia y [8/9, 135-150], [8/9, 151-157]

vid. historia

ficción, discurso histórico y [21/22, 215-246]

vid. discurso; historia

fictio personnae [13, 67-99]

filosofía

filosofía y estética [14, 7-8]

vid. estética

filosofía y retórica [14, 31-45]

vid. Retórica

filosofía, ensayo y [14, 17-30]

vid. ensayo

filosófica, escritura [14, 31-45]

vid. escritura

filosófico, transmisión del mensaje [14, 31-45]

Flores de filosofia [13, 227-251]

Investigaciones filosóficas (Ludwig Wittgenstein) [14, 79-89]

vid. Wittgenstein, Ludwig

Principia Philosophae (René Descartes) [14, 31-45]

vid. Descartes, René

fisiognomía [11, 141-153]

Flor de las ystorias de Orient (Juan Fernández de Heredia) [23/24/25, 11-41],

[23/24/25, 93-119]

vid. Fernández de Heredia, Juan; historia

Flores de filosofía [13, 227-251]

Flores, Juan de

Grimalte y Gradissa (Juan de Flores) [13, 5-18]

Florisando (Ruy Páez de Ribera) [11, 7-30]

vid. Páez de Ribera, Ruy

Follaje en los ojos (José M. Rivarola Matto) [21/22, 61-78]

vid. Rivarola Matto, José 
folletín en el siglo XIX [16, 89-101]

Fondo (Juan Manuel Villalba) [10, 149-151]

vid. Villalba, Juan Manuel

Fortuny de los Ríos, Francisco

Cielo rasante (Francisco Fortuny de los Ríos) [10, 140-143]

Freud, Sigmund [18, 87-99]

Frontaura, Carlos

Las Madres. Cuentos de Salón (Carlos Frontaura) [16, 89-101]

vid. cuento

Tipos madrileños (Carlos Frontaura) [16, 89-101]

Fuentes, Carlos

Gringo viejo (Carlos Fuentes) [8/9, 135-150]

Fulgencio, Fabio Plancíades

Mythologiarum Libri III (Fabio Plancíades Fulgencio) [13, 139-149]

vid. mito

Gallego, Vicente

Los ojos del extraño (Vicente Gallego) [10, 135-136]

Ganarás la luz (León Felipe) [6/7, 197-203]

vid. Felipe, León

Garay, María Eugenia

"Ciertas tardes" (María Eugenia Garay) [21/22, 139-151]

Garay, Blasco de

Cartas en refranes (Blasco de Garay) [13, 217-226]

vid. carta; refrán

García, Álvaro

La noche junto al álbum (Álvaro García) [10, 120-121]

vid. álbum

García Lorca, Federico

García Lorca, Federico [6/7, 189-196]

"Corazón bleu y coeur azul" (Federico García Lorca) [18, 13-23]

Federico García Lorca: heterodoxo y mártir (Eutimio Martín) [4, 113-120] vid. Martín, Eutimio

Los Putrefactos (García Lorca, Federico y Dalí, Salvador) [18, 13-23]

vid. Dalí, Salvador

“Oda a Salvador Dalí" (García Lorca, Federico) [18, 101-113]

vid. Dalí, Salvador

García Márquez, Gabriel

Cien años de soledad (Gabriel García Márquez) [8/9, 189-194] 
García Montero, Luis

García Montero, Luis [10, 97-105]

Habitaciones separadas (Luis García Montero) [10, 174-180]

genealogía

Genealogia deorum gentilium (Giovanni Boccaccio) [13, 19-31]

vid. Boccaccio, Giovanni

Genealogía, origen y noticias de los comediantes en España (Shergold, N. D. y Varey, J. E.) [17, 133-159], [17, 239-318]

vid. comedia

"Generación del 900" [21/22, 51-59]

generaciones literarias [10, 13-35]

género

género [19/20, 219-237]

género cuento [16, 133-142], [16, 171-187]

vid. cuento

género cuento en el siglo XIX [16, 89-101]

vid. cuento

género chico, zarzuela y $[\mathbf{1 5}, 77-88]$

género ensayístico [14, 31-45]

vid. ensayo

género "ensayo" [14, 7-8]

vid. ensayo

género fantástico [16, 57-87], [16, 103-118], [16, 119-132]

género fantástico en el siglo XIX [16, 47-56]

género gramatical y género erótico [19/20, 187-199]

vid. erótico

género popular de la Ilustración [15, 121-131]

género sainetil [15, 51-75]

vid. sainete

género trágico [17, 319-333]

géneros dramáticos breves $[15,77-88]$

vid. drama

géneros masculinos en la Edad Media, sexualidad y [19/20, 21-35]

vid. sexualidad

Gengis Khan [23/24/25, 11-41], [23/24/25, 93-119]

geografía

geografia cidiana [13, 59-65]

geografia escénica calderoniana [17, 47-63] 
Gil de Biedma, Jaime

"Nostalgie de la boue" (Jaime Gil de Biedma) [5, 81-87]

"De senectute" (Jaime Gil de Biedma) [5, 81-87]

Girondo, Oliverio

20 poemas para ser leídos en el tranvía (Oliverio Girondo) [6/7, 155-163]

vid. poema

Calcomanías (Oliverio Girondo) [6/7, 155-163]

Gómez Bueno de Acuña, Dora

"Decepción" (Dora Gómez Bueno de Acuña) [21/22, 139-151]

Góngora y Argote, Luis de

Góngora y Argote, Luis de [5, 17-29]

Soledades (Luis de Góngora y Argote) [11, 63-82]

González, Juan Natalicio

La raíz errante (Juan Natalicio González) [21/22, 79-96]

González de Clavijo, Ruy

Embajada a Tamorlán (Ruy González de Clavijo) [13, 179-191]

González del Castillo, Juan Ignacio [3, 58-76]

Gorodischer, Angélica [12, 91-100]

Gracián, Baltasar

El Criticón (Baltasar Gracián) [6/7, 15-23]

Oráculo manual y arte de prudencia (Baltasar Gracián) [6/7, 15-23]

gramáticas guaraníes [21/22, 9-32]

Grant Crónica d'Espanya (Juan Fernández de Heredia) [23/24/25, 155-176]

vid. crónica; Fernández de Heredia, Juan

Grimalte y Gradissa (Juan de Flores) [13, 5-18]

vid. Flores, Juan de

Gringo viejo (Carlos Fuentes) [8/9, 135-150]

vid. Fuentes, Carlos

Grupo del 40 [21/22, 111-123]

Guaman Poma de Ayala, Felipe

Nueva crónica y buen gobierno (Felipe Guaman Poma de Ayala) [11, 191-201] vid. crónica

Gutiérrez de Alba, José M.

Una mujer literata (José M. Gutiérrez de Alba) [15, 169-176]

vid. mujer

Guzmán de Alfarache (Mateo Alemán) [6/7, 15-23]

vid. Alemán, Mateo 
Guzmán, Martín Luis

El águila y la serpiente (Martín Luis Guzmán) [5, 123-136]

¡Ha che memby cuera! (Josefina Plá) [21/22, 191-200]

vid. Plá, Josefina

Habitaciones separadas (Luis García Montero) [10, 174-180]

vid. García Montero, Luis

hagiografia $[23 / 24 / 25,177-194]$

Hayton [23/24/25, 11-41]

heliómetro [18, 101-113]

herencia prometeica [14, 49-64]

vid. Prometeo

Hernández, José

Martín Fierro (José Hernández) [3, 92-104]

Hernández, Patricio

Emilio Prados: la memoria del olvido (Patricio Hernández) [5, 37-41]

vid. memoria

hidalguía y linaje [13, 115-137]

Hijo de hombre (Augusto Roa Bastos) [8/9, 159-170], [21/22, 215-246]

vid. Roa Bastos, Augusto

histeria [19/20, 141-161]

historia

Estoria de Espanna (Alfonso X) [19/20, 21-35], [23/24/25, 155-176]

vid. Alfonso X

Flor de las ystorias de Orient (Juan Fernández de Heredia) [23/24/25, 11-41],

[23/24/25, 93-119]

vid. Fernández de Heredia, Juan

Historia de la conquista de las siete islas Canarias (Juan de Abreu y Galindo)

$[13,151-171]$

vid. Abreu y Galindo, Juan de

Historia de mis libros (Rubén Darío) [6/7, 115-122]

vid. Darío, Rubén; libro

Historia Destructionis Troiae (Guido delle Colonne) [23/24/25, 65-91],

[23/24/25, 155-176]

vid. Colonne, Guido delle; Troya

historia literaria [4, 109-112]

historia literaria contemporánea [10, 13-35]

historia literaria hispanoamericana [8/9,325-333] 
Historia verdadera de la conquista de la Nueva España

(Bernal Díaz del Castillo) [8/9, 17-26]

vid. Díaz del Castillo, Bernal

"Historia verdadera" (Antonio Ros de Olano) [16, 57-87]

vid. Ros de Olano, Antonio

historia y ficción literaria [8/9, 135-150], [8/9, 151-157]

vid. ficción

historia y leyenda, comedias de [17, 89-112]

vid. comedia; leyenda

historia y novela [21/22, 247-257]

vid. novela

historias de aventuras [23/24/25, 177-194]

histórico y ficción, discurso [21/22, 215-246]

vid. discurso; ficción

histórico, cuento [16, 9-23]

vid. cuento

histórico, tragedia de corte [17, 319-333]

históricos, personajes [17, 319-333]

vid. personaje

históricos, personajes dramáticos [17, 113-131]

vid. drama; personaje

Histoire littéraire du sentiment religieux en France

(Henri Bremond) [6/7, 25-40]

vid. Bremond, Henri; religión

intrahistóricos, personajes [17, 319-333]

vid. personaje

La vera historia de la Purificación (Raquel Saguier) [21/22, 61-78]

vid. Saguier, Raquel

Qu'est-ce que l'histoire littéraire (Clément Moisan) [4, 109-112]

vid. Moisan, Clément

historiografía

discursos historiográficos [23/24/25, 43-64]

vid. discurso

historiografía [23/24/25, 11-41], [23/24/25, 155-176]

historiografia romana $[\mathbf{1 4}, 11-16]$

histrión

histrión $[15,29-50]$

histrión, primores del [15, 29-50] 
histriones [17, 161-176]

histriónica, declamación [15, 29-50]

vid. declamación

histrionismo de Dalí [18, 75-79]

vid. Dalí

homoerotismo [19/20, 187-199]

vid. erotismo

homofobia [19/20, 239-256]

homosexualidad y literatura [19/20, 257-280]

vid. literatura; sexualidad

honor [13, 193-206]

Hora de España (1937-1938) [4, 49-54]

Huarte de San Juan, Juan

Examen de ingenios para las ciencias (Juan Huarte de San Juan) [6/7, 15-23] hubris [13, 43-57]

Humanismo

Humanismo [13, 19-31], [23/24/25, 235-254], [23/24/25, 255-313]

humanística, narrativa [23/24/25, Roxana Recio ]

vid. narrativa

humor negro [16, 119-132]

Huidobro, Vicente

Altazor (Vicente Huidobro) [6/7, 145-154]

iconografía hagiográfica [13, 207-216]

identidad

identidad femenina [21/22, 125-138]

identidad gay [19/20, 239-256]

identidad narrativa, lengua e [21/22, 215-246]

vid. lengua

Iluminaciones (Walter Benjamin) [14, 103-112]

vid. Benjamin, Walter

ilusión escénica [15, 29-50]

imaginería medieval femenina [13, 207-216]

Infancia en Berlín hacia 1900 (Walter Benjamin) [14, 103-112]

vid. Benjamin, Walter

información

información, acceso a la [19/20, 257-280]

información, derecho a la [19/20, 257-280] 
insomnio de amor [13, 285-314]

vid. sueño

Insúa, Alberto [19/20, 141-161]

Las neuróticas (Alberto Insúa) [19/20, 141-161]

insularidad [21/22, 79-96]

intertextualidad y polifonía textual [21/22, 215-246]

vid. texto

intimidad [21/22, 201-214]

Investigaciones filosóficas (Ludwig Wittgenstein) [14, 79-89]

vid. Wittgenstein, Ludwig

Iriarte, Tomás de [15, 89-98]

Ishaq, Hunayn ibn

Libro de los buenos proverbios (Hunayn ibn Ishaq) [13, 227-251]

vid. libro

Jiménez Millán, Antonio

Casa invadida (Antonio Jiménez Millán) [10, 146-148]

Juan de Mairena (Antonio Machado) [6/7, 123-131]

vid. Machado, Antonio

Juan Manuel

Libro de los Estados (Juan Manuel) [13, 115-137]

vid. libro

Juan Rana en la Zarzuela (Pedro Calderón de la Barca) [17, 227-261]

vid. Calderón de la Barca, Pedro

Jové, Jordi [18, 9-11]

Juaristi, Jon [10, 167-169]

Juventud (Heriberto Fernández) [21/22, 111-123]

vid. Fernández, Heriberto

koiné

koiné, lírica de [23/24/25, 195-211]

vid. lírica

koiné napolitana [23/24/25, 195-211]

L'Amic de les Arts (1926-1929) [18, 101-113]

l'art pour l'art [18, 9-11]

La aurora en Copacabana (Pedro Calderón de la Barca) [17, 33-46]

vid. Calderón de la Barca, Pedro

La Babosa (Gabriel Casaccia) [21/22, 201-214]

vid. Casaccia, Gabriel 
La casa y la calle (José M. Matheu) [16, 149-156]

vid. Matheu, José M.

La Cecilia (Luciano Francisco Comella) [15, 133-144]

vid. Comella, Luciano Francisco

La condición del personaje (Álvaro Salvador) [10, 125-126]

vid. personaje; Salvador, Álvaro

La consagración de la primavera (Alejo Carpentier) [2, 85-97]

vid. Carpentier, Alejo

La consagración de la primavera (Igor Fiodorovich Stravinski) [2, 85-97]

vid. Stravinski, Igor Fiodorovich

La Dama Errante (Ángeles Mora) [10, 123-124]

vid. Mora, Ángeles

“La exposición” (Renée Ferrer) [21/22, 275-290]

vid. Ferrer, Renée

La expresión americana (José Lezama Lima) [19/20, 201-218]

vid. Lezama Lima, José

La Fantesca (Giambattista della Porta) [17, 161-176]

vid. Porta, Giambattista della

La femme visible (Dalí, Salvador) [18, 87-99]

vid. Dalí, Salvador

La Metamorfosis de Narciso (Dalí, Salvador) [18, 41-47]

vid. Dalí, Salvador; metamorfosis

La mala compañia (Felipe Benítez Reyes) [10, 158-160]

vid. Benítez Reyes, Felipe

"La noche de las máscaras" (Antonio Ros de Olano) [16, 57-87]

vid. Ros de Olano, Antonio

La noche junto al álbum (Álvaro García) [10, 120-121]

vid. álbum; García, Álvaro

La novela del Indio Tupinamba (Eugenio Fernández Granell) [4, 55-68]

vid. Fernández Granell, Eugenio; novela

La Novela Ideal (colección literaria: 1925-1938) [6/7, 181-187] vid. novela

La pipa de kif(Ramón María del Valle-Inclán) [3, 133-147]

vid. Valle-Inclán, Ramón María del

La Querida (Renée Ferrer) [21/22, 275-290]

vid. Ferrer, Renée

La Quête de Bronwyn (Juan Eduardo Cirlot) [5, 65-80]

vid. Cirlot, Juan Eduardo 
La raíz errante (Juan Natalicio González) [21/22, 79-96]

vid. González, Juan Natalicio

La Regenta (Leopoldo Alas "Clarín") [1, 5-13], [3, 105-113], [6/7, 83-90] vid. "Clarín" (Leopoldo Alas)

La rondeña (cuentos andaluces) (Blanca de los Ríos) [16, 171-187]

vid. cuento; Ríos, Blanca de los

"La saeta" (Blanca de los Ríos) [16, 171-187]

vid. Ríos, Blanca de los

La Seca y otros cuentos (Renée Ferrer) [21/22, 275-290]

vid. cuento; Ferrer, Renée

La soledad era esto (Juan José Millás) [6/7, 229-232]

vid. Millás, Juan José

"La solterona" (Delfina Acosta) [21/22, 125-138]

vid. Acosta, Delfina

La vera historia de la Purificación (Raquel Saguier) [21/22, 61-78]

vid. historia; Saguier, Raquel

La vida de frontera (Carlos Marzal) [10, 154-157]

vid. Marzal, Carlos; vida

La vida es sueño (Calderón de la Barca, Pedro) [17, 47-63]

vid. Calderón de la Barca, Pedro; vida

La vorágine (José Eustasio Rivera) [8/9, 249-254]

vid. Rivera, José Eustasio

Lamas, Teresa

Aquel viejo dolor (Teresa Lamas) [21/22, 79-96]

Lamillar, Juan

El paisaje infinito (Juan Lamillar) [10, 161-163]

Las casas de Madrid (Juan Francisco Tejera) [17, 177-209]

vid. Tejera, Juan Francisco

Las Casas, Bartolomé de [3, 48-57]

Las contracifras (Rafael Ballesteros) [6/7, 215-221]

vid. Ballesteros, Rafael

Las Madres. Cuentos de Salón (Carlos Frontaura) [16, 89-101]

vid. cuento; Frontaura, Carlos

Las neuróticas (Alberto Insúa) [19/20, 141-161]

vid. Insúa, Alberto

Las muñecas de Marcela (Álvaro Cubillo de Aragón) [17, 89-112]

vid. Cubillo de Aragón, Álvaro 
Las Sergas de Esplandián (Garci Rodríguez de Montalvo) [11, 7-30] vid. Rodríguez de Montalvo, Garci

Le Bossu (Paul Féval) [15, 177-189] vid. Féval, Paul

Le Théâtre de Clara Gazul (Prosper Merimée) [15, 159-168] vid. Merimée, Prosper; teatro

Lebrón, Maybell

"Poeta" (Maybell Lebrón) [21/22, 125-138]

lectura y creación $[\mathbf{1 4}, 7-8]$

lengua

lengua aragonesa [23/24/25, 11-41], [23/24/25, 121-153], [23/24/25, 65-91]

lengua e identidad narrativa [21/22, 215-246] vid. identidad

lengua guaraní [21/22, 9-32]

lengua inglesa, mujer en la literatura contemporánea en [12, 153-171]

lenguaje vid. literatura; mujer

lenguaje dualista [14, 79-89]

lenguaje, precisión del [14, 79-89]

León, Rafael de [19/20, 187-199]

ley

leyes de la naturaleza $[\mathbf{1 4}, 79-89]$

leyes humanas $[\mathbf{1 4}, 79-89]$

leyenda

leyenda romántica [16, 9-23]

vid. Romanticismo

leyenda, comedias de historia y $[\mathbf{1 7}, 89-112]$

vid. comedia; historia

Leyendas (Gustavo Adolfo Bécquer) [16, 47-56]

vid. Bécquer, Gustavo Adolfo

leyendas fantásticas [16, 119-132]

Lezama Lima, José

Paradiso (José Lezama Lima) [19/20, 201-218]

La expresión americana (José Lezama Lima) [19/20, 201-218] libro

Historia de mis libros (Rubén Darío) [6/7, 115-122]

vid. Darío, Rubén 
Libre dels feyts del rei en Jacme [13, 285-314]

Libro de Alexandre [13, 227-251]

vid. Alexandre

Libro de Apolonio [13, 193-206]

Libro de las maravillas del mundo (Juan de Mandevilla) [13, 179-191]

vid. Mandevilla, Juan de

Libro de los buenos proverbios (Hunayn ibn Ishaq) [13, 227-251]

vid. Ishaq, Hunayn ibn

Libro de los cien capitulos [13, 227-251]

Libro de los Estados (Juan Manuel) [13, 115-137]

vid. Juan Manuel

Libro del caballero Zifar [13, 115-137]

vid. caballería

Libro de la Vida (Teresa de Jesús) [19/20, 57-73]

vid. Cepeda y Ahumada, Teresa (Teresa de Jesús); vida

Llibre de meravelles (Ramon Llull) [13, 179-191]

vid. Llull, Ramon

Los siete libros de la Diana (Jorge de Montemayor) [4, 21-33]

vid. Montemayor, Jorge de

Linares, Abelardo

Espejos (Abelardo Linares) [10, 132-134]

lírica

lírica de koiné [23/24/25, 195-211]

lírica popular hispánica [13, 277-284]

literatura

literatura anarquista [6/7, 181-187]

literatura argentina, mujer en la [12, 91-100]

vid. mujer

literatura caballeresca [13, 101-113]

vid. caballería

literatura colonial hispanoamericana [8/9, 27-35]

literatura contemporánea en lengua inglesa, mujer en la [12, 153-171]

vid. mujer, lengua

literatura cubana [19/20, 201-218]

literatura de alegato crítico medieval española $[\mathbf{1 3}, 151-171]$

vid. crítica

literatura de denuncia política [21/22, 247-257], [21/22, 259-273] 
literatura española (bibliografía), mujer en la [12, 185-214]

vid. bibliografía

literatura española del exilio [8/9, 335-340], [8/9, 359-368]

literatura fantástica [16, 103-118], [16, 119-132]

literatura gay y lesbiana [19/20, 257-280]

literatura griega clásica, mujer en la [12, 13-31]

vid. mujer

literatura médica tardomedieval [13, 253-275]

literatura mejicana, mujer en la [12, 77-89]

vid. mujer

literatura misógina [13, 285-314]

literatura novecentista catalana, mujer en la [12, 101-128]

vid. mujer

literatura occidental (bibliografía), mujer en la [12, 215-252]

vid. bibliografía; mujer

literatura paraguaya del siglo XX [21/22]

literatura paraguaya, temas de la [21/22, 51-59]

literatura política española del siglo XV [13, 67-99]

literatura sapiencial [13, 227-251]

literatura social paraguaya [21/22, 153-171]

literatura y ética $[14,7-8]$

vid. ética

literatura, homosexualidad y [19/20, 257-280]

vid. sexualidad

literatura, mujer en la [12, 7-12]

vid. mujer

Livio, Tito

Livio, Tito [14, 11-16], [23/24/25, 213-233]

Ab urbe condita (Tito Livio) [23/24/25, 213-233]

Llibre de meravelles (Ramon Llull) [13, 179-191]

vid. libro; Llull, Ramon

Llull, Ramon

Llibre de meravelles (Ramon Llull) [13, 179-191]

vid. libro

Lo que son los yerbales (Rafael Barret) [21/22, 153-171]

vid. Barret, Rafael

Lo somni (Bernat Metge) [13, 285-314]

vid. Metge, Bernat; sueño 
locus amoenus [21/22, 79-96]

$\log o s[14,17-30]$

López, Nila

"Madre, hija y espíritu santo" (Nila López) [21/22, 125-138]

López de Mendoza, Íñigo [13, 207-216]

López de Yanguas, Hernán

Égloga de la Natividad (Hernán López de Yanguas) [17, 113-131]

Farsa del Mundo y Moral (Hernán López de Yanguas) [17, 113-131] vid. farsa

Farsa Turquesana (Hernán López de Yanguas) [17, 113-131] vid. farsa

Los bandos del Avapiés (Ramón de la Cruz Cano y Olmedilla) [15, 51-75]

vid. Cruz Cano y Olmedilla, Ramón de la

Los de abajo (Mariano Azuela) [5, 123-136]

vid. Azuela, Mariano

Los de entonces (Recuerdos) (María Pilar Donoso) [8/9, 111-118]

vid. Donoso, María Pilar

Los jeroglíficos del caballo (Eduardo Chicharro) [2, 63-73]

vid. Chicharro, Eduardo

Los Juan Ranas (baile) [17, 227-261]

vid. baile

Los mártires del “Freeway” (Carlos Martín Briceño) [19/20, 239-256]

vid. Martín Briceño, Carlos

Los mejores años (Javier Salvago) [10, 127-131]

vid. Salvago, Javier

Los nudos del silencio (Renée Ferrer) [21/22, 275-290]

vid. Ferrer, Renée; silencio

Los ojos del extraño (Vicente Gallego) [10, 135-136]

vid. Gallego, Vicente

Los Putrefactos (García Lorca, Federico y Dalí, Salvador) [18, 13-23]

vid. Dalí, Salvador; García Lorca, Federico

Los Santos Inocentes (Miguel Delibes) [5, 89-98]

vid. Delibes, Miguel

Los siete libros de la Diana (Jorge de Montemayor) [4, 21-33]

vid. libro; Montemayor, Jorge de

Los trabajos de Persiles y Sigismunda (Miguel de Cervantes Saavedra) [11, 83-91]

vid. Cervantes Saavedra, Miguel de

Lucano, Marco Anneo [17, 319-333] 
Farsalia (Marco Anneo Lucano) [17, 319-333]

"Lucha hasta el alba" (Augusto Roa Bastos) [1, 91-96]

vid. Roa Bastos, Augusto

Lucrecia (personaje legendario romano) [12, 33-49]

Luque, Aurora

Carpe noctem (Aurora Luque) [10, 122]

Lloréns Torres, Luis [19/20, 163-185]

"Macario" (Juan Rulfo) [8/9, 213-218]

vid. Rulfo, Juan

Machado, Antonio

Machado, Antonio [6/7, 189-196]

Juan de Mairena (Antonio Machado) [6/7, 123-131]

"Madre, hija y espíritu santo" (Nila López) [21/22, 125-138]

vid. López, Nila

Madrigal "el Tostado", Alfonso de

Diez qüestiones vulgares (Alfonso de Madrigal "el Tostado") [13, 19-31], [13, 139-149]

Magdaleno, Mauricio

El resplandor (Mauricio Magdaleno) [5, 123-136]

Mandevilla, Juan de [13, 179-191]

Libro de las maravillas del mundo (Juan de Mandevilla) [13, 179-191]

vid. libro

Manierismo [17, 161-176]

Manifiesto de María de Navas, la Comedianta [17, 177-209]

Manual del librero hispanoamericano (Antonio Palau y Dulcet) [13, 173-178]

vid. Palau y Dulcet, Antonio

manuales mitográficos medievales [13, 139-149]

vid. mito

March, Ausiàs

"Axí com cell qui.n lo somni.s delita" (Ausiàs March) [3, 24-47]

Marcha (1939-1975) [8/9, 119-128]

Marín, Pero

Miraculos romançados (Pero Marín) [13, 285-314]

Marsé, Juan [3, 148-166]

Martí, José [2, 75-83], [6/7, 105-114]

Martín Briceño, Carlos

Los mártires del "Freeway" (Carlos Martín Briceño) [19/20, 239-256] 
Martín Fierro (José Hernández) [3, 92-104]

vid. Hernández, José

Martín Santos, Luis

Tiempo de silencio (Luis Martín Santos) [5, 99-114]

vid. silencio

Martín, Eutimio

Federico García Lorca: heterodoxo y mártir (Eutimio Martín) [4, 113-120]

vid. García Lorca, Federico

Marzal, Carlos

El último de la fiesta (Carlos Marzal) [10, 154-157]

La vida de frontera (Carlos Marzal) [10, 154-157]

vid. vida

"Mas vale traque que Dios vos salue" [13, 217-226]

máscara de parejas $[\mathbf{1 7}, 7-31]$

materia de Troya [23/24/25, 155-176], [23/24/25, 65-91]

vid. Troya

materiales GLTBQ [19/20, 257-280]

Matheu, José M.

La casa y la calle (José M. Matheu) [16, 149-156]

"Maximino Maury" (José M. Matheu) [16, 149-156]

Matto de Turner, Clorinda [8/9, 73-82]

"Maximino Maury" (José M. Matheu) [16, 149-156]

vid. Matheu, José M.

Melalcor (Flavia Company) [19/20, 219-237]

vid. Company, Flavia

Méditations (René Descartes) [14, 17-30]

vid. Descartes, René

Medora (Lope de Rueda) [17, 211-225]

vid. Rueda, Lope de

melólogo [15, 89-98]

memoria

memoria colectiva [21/22, 215-246]

memorias [21/22, 33-49]

"A la memoria de mi Hermano" (Carmen Casartelli) [21/22, 125-138] vid. Casartelli, Carmen

Emilio Prados: la memoria del olvido (Patricio Hernández) [5, 37-41] vid. Hernández, Patricio

Mendoza, doña Mencía de [13, 207-216] 
Merimée, Prosper

Le Théâtre de Clara Gazul (Prosper Merimée) [15, 159-168] vid. teatro

Merimée, sátira en [15, 159-168]

Mesa, Cristóbal de

El Pompeyo (Cristóbal de Mesa) [17, 319-333]

Mesa Toré, José Antonio

El amigo imaginario (José Antonio Mesa Toré) [10, 144-145]

metáforas bíblicas [13, 19-31]

metamorfosis

Allegoriae super Ovidii Metamorphosin (Adolfo d'Orleans) [13, 139-149] vid. alegoría; Orleans, Adolfo d'

La Metamorfosis de Narciso (Dalí, Salvador) [18, 41-47]

vid. Dalí, Salvador

Metamorfosis (Publio Ovidio Nasón) [13, 19-31], [13, 139-149] vid. Ovidio Nasón, Publio

metateatralidad [17, 211-225]

Metge, Bernat

Lo somni (Bernat Metge) [13, 285-314]

vid. sueño

Valter e Griselda (Bernat Metge) [23/24/25, 235-254]

método paranoico-crítico [18, 87-99], [18, 101-113]

vid. crítica

Mexía, Pedro

Silva de varia lección (Pedro Mexía) [13, 285-314]

Mi primer ensayo (Casta Esteban y Navarro) [14, 65-71]

vid. Esteban y Navarro, Casta; ensayo

Mi primera campaña (Rafael Altamira) [6/7, 91-104]

vid. Altamira, Rafael

Mi vida con Leopoldo Marechal (Elbia Rosbaco Marechal) [8/9, 111-118]

vid. Rosbaco Marechal, Elbia; vida

Millás, Juan José

La soledad era esto (Juan José Millás) [6/7, 229-232]

Mimesis [21/22, 259-273]

mirabilia $[\mathbf{1 3}, 179-191]$

Miraculos romançados (Pero Marín) [13, 285-314]

vid. Marín, Pero 
misiones jesuíticas de los siglos XVII y XVIII [21/22, 9-32]

misoginia

misoginia medieval [19/20, 37-56]

misoginia sexual [19/20, 75-93]

vid. sexualidad

mito

mito Dalí [18, 25-39]

vid. Dalí, Salvador

mito de 'don Juan' [15, 99-120], [17, 263-277]

mito de San Sebastián [18, 101-113]

mitográficos medievales, manuales [13, 139-149]

mitológico, teatro [17, 279-292]

vid. teatro

Mythologiarum Libri III (Fabio Plancíades Fulgencio) [13, 139-149]

vid. Fulgencio, Fabio Plancíades

modelos femeninos [19/20, 95-100], [21/22, 291-308]

modernidad poética $[\mathbf{1 4}, 103-112]$

vid. poética

Moisan, Clément

Qu'est-ce que l'histoire littéraire (Clément Moisan) [4, 109-112]

vid. historia

mojiganga

mojiganga [17, 7-31]

mojiganga dramática [17, 227-261]

vid. drama

Montaigne, Michel de

Essais (Michel de Montaigne) [14, 17-30]

vid. ensayo

Montemayor, Jorge de

Los siete libros de la Diana (Jorge de Montemayor) [4, 21-33]

vid. libro

Montseny, Federica [6/7, 181-187]

Mora, Ángeles

La Dama Errante (Ángeles Mora) [10, 123-124]

morbo (enfermedad) [13, 253-275]

Moreno, Luisa

Ecos de monte y de arena (Luisa Moreno) [21/22, 61-78]

movimiento obrero paraguayo [21/22, 153-171] 
mujer

mujer en la literatura [12, 7-12]

vid. literatura

mujer en la literatura argentina [12,91-100]

vid. literatura

mujer en la literatura contemporánea en lengua inglesa [12, 153-171]

vid. lengua; literatura

mujer en la literatura española (bibliografía) [12, 185-214]

vid. bibliografía; literatura

mujer en la literatura griega clásica [12, 13-31]

vid. literatura

mujer en la literatura mejicana [12, 77-89]

vid. literatura

mujer en la literatura novecentista catalana [12, 101-128]

vid. literatura

mujer en la literatura occidental (bibliografía) [12, 215-252]

vid. bibliografía; literatura

mujer literata española de mediados del siglo XIX [15, 169-176]

"La mujer paraguaya" (Ignacio A. Pane) [21/22, 79-96]

vid. Pane, Ignacio A.

mujeres [19/20, 57-73]

mujer, valores y derechos de la [14, 65-71]

"Nacer Mujer-Poeta" (Lourdes Espínola) [21/22, 125-138]

vid. Espínola, Lourdes; poeta

Una mujer literata (José M. Gutiérrez de Alba) [15, 169-176]

vid. Gutiérrez de Alba, José M.

Muñoz Molina, Antonio

Beltenebros (Antonio Muñoz Molina) [6/7, 223-227]

Muñoz, Luis

Septiembre (Luis Muñoz) [10, 116-119]

música y poesía española actual $[\mathbf{1 0}, 107-112]$

vid. poesía

Mythologiarum Libri III (Fabio Plancíades Fulgencio) [13, 139-149]

vid. Fulgencio, Fabio Plancíades; mito

"Nacer Mujer-Poeta" (Lourdes Espínola) [21/22, 125-138]

vid. Espínola, Lourdes; mujer; poeta

narcisismo creador $[\mathbf{1 8}, 49-63]$ 
narrativa

narrativa castellana medieval [13, 193-206]

narrativa humanística [23/24/25, 235-254]

vid. Humanismo

narrativa paraguaya contemporánea [21/22, 61-78]

narrativa paraguaya del siglo XX [21/22, 51-59]

narrativa, lengua e identidad [21/22, 215-246]

vid. lengua, identidad

naturaleza [21/22, 61-78]

Naturalismo

Naturalismo [16, 157-170]

realistas-naturalistas, cuentos [16, 171-187]

vid. cuento; Realismo

Navarro, Justo

Un aviador prevé su muerte (Justo Navarro) [5, 115-121]

Navas, María de [17, 177-209]

neoanalfabetos parciales [14, 73-78]

vid. analfabetismo

neoanalfabetos totales [14, 73-78]

vid. analfabetismo

Neruda, Pablo

Neruda, Pablo [6/7, 165-174], [8/9, 239-248]

No hay plazo que no se cumpla ni deuda que no se pague, y convidado de piedra

(Antonio de Zamora) [15, 99-120]

vid. Zamora, Antonio de

"Non como quien se desvela" (Alfonso de la Torre) [13, 33-42]

vid. Torre, Alfonso de la

"Nostalgie de la boue" (Jaime Gil de Biedma) [5, 81-87]

vid. Gil de Biedma, Jaime

novecentismo catalán [12, 101-128]

novela

La novela del Indio Tupinamba (Eugenio Fernández Granell) [4, 55-68]

vid. Fernández Granell, Eugenio

La Novela Ideal (colección literaria: 1925-1938) [6/7, 181-187]

novela de caballerías [13, 193-206]

vid. caballería

novela de capa y espada [15, 177-189]

novela de la dictadura [21/22, 247-257] 
novela de la revolución mexicana [5, 123-136]

novela del dictador [21/22, 275-290], [21/22, 291-308]

novela gay mexicana del siglo XX [19/20, 239-256]

novela hispanoamericana actual $[\mathbf{8} / \mathbf{9}, 151-157]$

novela paraguaya del siglo XX [21/22, 201-214], [21/22, 247-257],

[21/22, 275-290]

novela político-sociológica de suspense en Paraguay [21/22, 97-109]

novela sentimental [13, 5-18], [13, 193-206]

novela, historia y [21/22, 247-257]

vid. historia

Nuestra elegía (Alfonso Costafreda) [1, 49-64]

vid. Costafreda, Alfonso

Nueva crónica y buen gobierno (Felipe Guaman Poma de Ayala) [11, 191-201]

vid. Guaman Poma de Ayala, Felipe; crónica

nueva poesía cubana de los años 80 [8/9, 297-323]

obra / marco [17, 211-225]

"Oda a Platko" (Rafael Alberti) [4, 77-90]

vid. Alberti, Rafael

"Oda a Salvador Dalí" (García Lorca, Federico) [18, 101-113]

vid. Dalí, Salvador; García Lorca, Federico

Ojo por diente (Rubén Bareiro Saguier) [21/22, 259-273]

vid. Bareiro Saguier, Rubén

onanismo [18, 49-63]

onomatopeyas [13, 217-226]

Oquendo de Amat, Carlos

5 metros de poemas (Carlos Oquendo de Amat) [8/9, 255-265]

vid. poema

Oráculo manual y arte de prudencia (Baltasar Gracián) [6/7, 15-23]

vid. Gracián, Baltasar

oralidad / escritura [14, 17-30], [21/22, 215-246]

vid. escritura

Orleans, Adolfo d'

Allegoriae super Ovidii Metamorphosin (Adolfo d'Orleans) [13, 139-149] vid. alegoría; metamorfosis

Ortega y Gasset, José [6/7, 133-144]

Ory, Carlos Edmundo de [1, 37-47]

Ovidio Nasón, Publio

Metamorfosis (Publio Ovidio Nasón) [13, 19-31], [13, 139-149] 
vid. metamorfosis

ovidiana, alegoría [13, 139-149]

vid. alegoría

Páez de Ribera, Ruy

Florisando (Ruy Páez de Ribera) [11, 7-30]

palabras y significado [14, 79-89]

Palau y Dulcet, Antonio

Manual del librero hispanoamericano (Antonio Palau y Dulcet) [13, 173-178]

Palés Matos, Luis [19/20, 163-185]

Palmerín de Olivia [5, 7-16], [13, 173-178]

Pane, Ignacio A.

"La mujer paraguaya" (Ignacio A. Pane) [21/22, 79-96]

Panero, Leopoldo María [1, 67-75]

Paradiso (José Lezama Lima) [19/20, 201-218]

vid. Lezama Lima, José

Paraguay [21/22]

paratexto literario $[\mathbf{1 9 / 2 0}, 37-56]$

vid. texto

Pardo Bazán, Emilia [12, 51-75]

paremia $[13,217-226]$

vid. refrán

Parodi, Enrique

"Patria" [21/22, 79-96]

parodia

Parodia de Guzmán el Bueno (Félix María de Samaniego) [15, 89-98]

vid. Samaniego, Félix María de

parodia y comedia $[\mathbf{1 5}, 89-98]$

vid. comedia

Partida Segunda (Alfonso X) [13, 101-113], [13, 115-137]

vid. Alfonso $\mathrm{X}$

Paseo de los tristes (Javier Egea) [10, 170-173]

vid. Egea, Javier

"Patria" (Enrique Parodi) [21/22, 79-96]

vid. Parodi, Enrique

Paz, Octavio

El mono gramático (Octavio Paz) [14, 93-102]

Penumbra hembra y otros desencuentros (Shirley Villalba) [21/22, 319-327]

vid. Villalba, Shirley 
peones y barruntes $[13,115-137]$

Peregrino de la eternidad (Renée Ferrer) [21/22, 309-317]

vid. Ferrer, Renée

Pérez Galdós, Benito [12, 51-75], [19/20, 111-139]

Trafalgar (Benito Pérez Galdós) [6/7, 73-81]

Tristana (Benito Pérez Galdós) [19/20, 111-139]

Pérez, Antonio

Aforismos (Antonio Pérez) [11, 165-178]

Cartas españolas (Antonio Pérez) [11, 165-178]

vid. carta

Relaciones (Antonio Pérez) [11, 165-178]

Peri Rossi, Cristina [8/9, 219-227], [8/9, 229-237]

personaje

La condición del personaje (Álvaro Salvador) [10, 125-126]

vid. Salvador, Álvaro

personaje cómico [15, 145-158]

vid. cómico

personaje Dalí [18, 65-69]

vid. Dalí, Salvador

personaje dramático, construcción del [17, 113-131]

vid. drama

personajes dramáticos alegóricos $[\mathbf{1 7}, 113-131]$

vid. alegoría; drama

personajes dramáticos históricos [17, 113-131]

vid. drama; historia

personajes dramáticos pastoriles [17, 113-131]

vid. drama

personajes históricos [17, 319-333]

vid. historia

personajes intrahistóricos [17, 319-333]

vid. historia

personajes mirantes / personajes mirados [17, 211-225]

Peste Negra (137-1351) [13, 253-275]

Petrarca, Francesco

Petrarca, Francesco [23/24/25, 213-233]

Petrarca, prácticas traductológicas [23/24/25, 235-254]

vid. traducción 
Africa (Francesco Petrarca) [23/24/25, 213-233]

"Pez perseguido por una uva" (Dalí, Salvador) [18, 13-23]

vid. Dalí, Salvador

Picón, Jacinto Octavio

Drama de familia (Jacinto Octavio, Picón) [16, 157-170]

Piquero, José Luis

El buen discípulo (José Luis Piquero) [11, 115]

Plá, Josefina

Plá, Josefina [21/22, 111-123], [21/22, 153-171], [21/22, 291-308]

El espejo y el canasto (Josefina Plá) [21/22, 51-59]

"Soy como el mar" / El polvo enamorado (Josefina Plá) [21/22, 139-151]

El precio de los sueños (Josefina Plá) [21/22, 173-190]

vid. sueño

¿A dónde irás ña Romualda? (Josefina Plá) [21/22, 191-200]

¡Ha che memby cuera! (Josefina Plá) [21/22, 191-200]

Platón

Platón [14, 17-30]

platónicos, diálogos [14, 31-45]

vid. diálogo

Protágoras (Platón) [14, 49-64]

Plutarco

Plutarco [2, 117-123], [23/24/25, 121-153], [23/24/25, 255-313]

Vidas Paralelas (Plutarco) [23/24/25, 121-153]

vid. vida

Pobrecito poeta que era yo... (Roque Dalton) [8/9, 291-296]

vid. Dalton, Roque

poema

20 poemas para ser leídos en el tranvía (Oliverio Girondo) [6/7, 155-163]

vid. Girondo, Oliverio

5 metros de poemas (Carlos Oquendo de Amat) [8/9, 255-265]

vid. Oquendo de Amat, Carlos

8 poemas (Alfonso Costafreda) [1, 49-64]

vid. Costafreda, Alfonso

Poema de Fernán González [13, 285-314]

Poema de Mio Cid [13, 59-65], [13, 193-206]

"poema paranoico" [18, 41-47]

Poemas póstumos (César Vallejo) [4, 97-106]

vid. Vallejo, César 
poesía

poesía amorosa de Pedro Salinas [14, 127-128]

vid. Salinas, Pedro

poesía cubana de los años 80, nueva [8/9, 297-323]

poesía de cancionero del siglo XV [13, 33-42]

poesía de Salvador Dalí [18, 87-99]

vid. Dalí, Salvador

poesía de la experiencia [10, 37-52], [10, 93-95]

poesía dialogada [13, 33-42]

vid. diálogo

poesía erótica femenina [21/22, 139-151]

vid. erótico

poesía española actual $[\mathbf{1 0}, 53-67],[\mathbf{1 0}, 69-74]$

poesía española actual y ciudad [10, 75-91]

vid. ciudad

poesía española actual y música [10, 107-112]

vid. música

poesía española contemporánea [6/7, 175-180]

poesía femenina [21/22, 125-138], [21/22, 139-151], [21/22, 309-317]

poesía frente a sabiduría [13, 19-31]

poesía modernista de Puerto Rico [19/20, 163-185]

poesía paraguaya contemporánea [21/22, 319-327]

poesía paraguaya de vanguardia [21/22, 111-123]

vid. vanguardia

poesía paraguaya del siglo XX [21/22, 125-138], [21/22, 139-151], [21/22, 309-317]

poesía, poeta y ciudad [14, 103-112]

vid. ciudad; poeta

poesía sacra [13, 19-31]

poesía y teología $[13,19-31]$

ut pictura poesis $[\mathbf{1 1}, 155-164]$

poeta

"Nacer Mujer-Poeta" (Lourdes Espínola) [21/22, 125-138]

vid. Espínola, Lourdes; mujer

"Poeta" (Maybell Lebrón) [21/22, 125-138]

vid. Lebrón, Maybell

poeta irónico y poeta grosero [15, 11-27]

poeta y ciudad, poesía [14, 103-112]

vid. ciudad; poesía 
poética

Poética (Aristóteles) [15, 11-27]

vid. Aristóteles

poética femenina, voz [21/22, 319-327]

poética, modernidad [14, 103-112]

poéticas de posguerra, antologías [2, 29-37]

vid. antología; posguerra

poético, simbolismo [21/22, 173-190]

Polonia calderoniana [17, 47-63]

vid. Calderón de la Barca, Pedro

Porta, Giambattista della [17, 161-176]

La Fantesca (Giambattista della Porta) [17, 161-176]

posguerra

posguerra, antologías poéticas de [2, 29-37]

vid. antología; poética

posguerra española, intelectuales de la [4, 121-123]

Postismo [11, 37-47]

práctica y teoría de la risa $[\mathbf{1 5}, 11-27]$

vid. risa

Prado, Benjamín

El corazón azul del alumbrado (Benjamín Prado) [10, 152-153]

Prados, Emilio

Emilio Prados: la memoria del olvido (Patricio Hernández) [5, 37-41]

vid. Hernández, Patricio; memoria

praefationes $[\mathbf{1 4}, 11-16]$

precisión del lenguaje [14, 79-89]

vid. lenguaje

Primaleón [13, 173-178]

primer galán de teatro [17, 177-209]

primera dama de teatro $[\mathbf{1 7}, 177-209]$

Primer viaje (Cristóbal Colón) [13, 179-191]

vid. Colón, Cristóbal; viaje

primores del histrión $[15,29-50]$

vid. histrión

Principia Philosophae (René Descartes) [14, 31-45]

vid. Descartes, René; filosofía

prohibiciones de comedias [17, 65-87]

vid. comedia 
Prometeo [14, 49-64]

prometeica, herencia [14, 49-64]

Prometeo Encadenado (Esquilo) [14, 49-64]

vid. Esquilo

"Prosa para un fin de capítulo" (Carlos Barral) [2, 51-61]

vid. Barral, Carlos

prosa programática latina $[\mathbf{1 4}, 11-16]$

Protágoras (Platón) [14, 49-64]

vid. Platón

Pujols, Francesc [18, 25-39]

Purgatorio (Raúl Zurita) [8/9, 283-290]

vid. Zurita, Raúl

queer (Teoría)

queer [19/20, 257-280]

Queer Iberia [19/20, 9-20]

queer, rescritura [19/20, 219-237]

queer, teoría [19/20, 9-20]

Qu'est-ce que l'histoire littéraire (Clément Moisan) [4, 109-112]

vid. historia; Moisan, Clément

quête [5, 65-80], [13, 5-18]

Quevedo y Villegas, Francisco de

Quevedo y Villegas, Francisco de [4, 35-41], [5, 17-29]

"A Roma sepultada en sus ruinas" (Francisco de Quevedo y Villegas) [11, 31-42]

Vida del buscón llamado Pablos (Francisco de Quevedo y Villegas) [6/7, 73-81] vid. vida

Quien calla, otorga (Tirso de Molina) [11, 43-62]

vid. Tirso de Molina (fray Gabriel Téllez)

Quijote

Don Quijote de la Mancha (Miguel de Cervantes Saavedra) [6/7, 15-23]

vid. Cervantes Saavedra, Miguel de

Quijote de Avellaneda (Alonso Fernández de Avellaneda) [19/20, 75-93] vid. Fernández de Avellaneda, Alonso

Rama, Ángel [8/9, 119-128]

Ramírez de Guzmán, Catalina Clara [11, 155-164]

Rana, Juan [17, 227-261]

Rayuela (Julio Cortázar) [1, 77-89]

vid. Cortázar, Julio 
Realismo

Realismo [16, 157-170]

realistas-naturalistas, cuentos [16, 171-187]

vid. cuento; Naturalismo

recepción de la caballería $[\mathbf{1 3}, 101-113]$

vid. caballería

refrán

Cartas en refranes (Blasco de Garay) [13, 217-226]

vid. carta; Garay, Blasco de

paremia [13, 217-226]

Refranero arábigoandaluz [13, 217-226]

Refranero español [13, 217-226]

Refranes que dizen las viejas tras el fuego [13, 217-226]

regimen sanitatis [13, 253-275]

regimiento de príncipes [13, 227-251]

Relaciones (Antonio Pérez) [11, 165-178]

vid. Pérez, Antonio

Relativismo [14, 113-125]

relato

relato biográfico medieval $[13,227-251]$

vid. biografía

relatos cómicos [16, 133-142]

vid. cómico

relato testimonial $[\mathbf{8} / \mathbf{9}, 99-110]$

relatos de naufragios $[\mathbf{8} / \mathbf{9}, 37-51]$

relatos de viajes medievales [13, 179-191]

vid. viaje

relatos fantásticos [16, 47-56]

religión

Histoire littéraire du sentiment religieux en France (Henri Bremond) [6/7, 25-40]

vid. Bremond, Henri; historia

religión [21/22, 259-273]

religiones, silencio, culturas y [14, 93-102]

vid. silencio

religiosas, comedias [17, 89-112]

vid. comedia

Repertorio de Príncipes de España [13, 285-314]

Réquiem por un campesino español (Ramón J. Sender) [4, 69-75] 
vid. Sender, Ramón J.

Res Gestae (Sempronio Aselión) [2, 111-115], [14, 11-16]

vid. Aselión, Sempronio

rescritura queer [19/20, 219-237]

vid. queer (Teoría)

retablo de Santa Ana (Gil de Siloe) [13, 207-216]

vid. Siloe, Gil de

retablo femenino [13, 207-216]

Retórica

Retórica [23/24/25, 43-64], [23/24/25, 65-91]

retórica, filosofía y [14, 31-45]

vid. filosofía

retrato literario [11, 155-164]

revolución mexicana, novela de la [5, 123-136]

vid. novela

Reyes Católicos [13, 151-171]

ridículo, lo [15, 11-27]

Ríos, Blanca de los

La rondeña (cuentos andaluces) (Blanca de los Ríos) [16, 171-187]

vid. cuento

"La saeta" (Blanca de los Ríos) [16, 171-187]

El salvador (cuentos varios) (Blanca de los Ríos) [16, 171-187]

vid. cuento

Ríos, Joaquín

Últimos domicilios (Joaquín Ríos) [10, 137-139] risa

Cancionero de obras de burlas provocantes a risa [19/20, 37-56]

carcajada romántica [15, 99-120]

vid. Romanticismo

risa costumbrista [15, 99-120]

vid. Costumbrismo

risa, causas y reglas de la [15, 11-27]

risa, práctica y teoría de la $[\mathbf{1 5}, 11-27]$

Rivarola Matto, José M.

Follaje en los ojos (José M. Rivarola Matto) [21/22, 61-78]

Rivera, José Eustasio

La vorágine [8/9, 249-254] 
Tierra de promisión [8/9, 249-254]

Roa Bastos, Augusto

Roa Bastos, Augusto [21/22, 33-49], [21/22, 153-171], [21/22, 215-246], [21/22, 247-257]

"Lucha hasta el alba" (Augusto Roa Bastos) [1, 91-96]

Hijo de hombre (Augusto Roa Bastos) [8/9, 159-170], [21/22, 215-246]

Yo el Supremo (Augusto Roa Bastos) [8/9, 171-188], [21/22, 33-49], [21/22, 51-59], [21/22, 247-257]

Yo el supremo / El trueno entre las hojas (Augusto Roa Bastos) [21/22, 61-78] Rodríguez Alcalá, Guido

El peluquero francés (Guido Rodríguez Alcalá) [21/22, 291-308]

Rodríguez de Montalvo, Garci

Amadis de Gaula (Garci Rodríguez de Montalvo) [13, 193-206], [19/20, 75-93]

Las Sergas de Esplandián (Garci Rodríguez de Montalvo) [11, 7-30]

Rodríguez Rubí, Tomás y Basili, Basilio

El contrabandista (Tomás Rodríguez Rubí y Basilio Basili) [15, 77-88]

Roman de Troie (Benoît de Sainte-Maure) [23/24/25, 155-176]

vid. Sainte-Maure, Benoît de; Troya

romance

Romance (1940-1941) [5, 43-50], [6/7, 189-196]

romance histórico [16, 9-23]

Romancero [13, 193-206]

romances juglarescos y carolingios [13, 43-57]

Romanticismo

Romanticismo [15, 159-168], [16, 47-56]

romántica, carcajada $[\mathbf{1 5}, 99-120]$

vid. risa

romántica, cosmovisión [16, 57-87]

romántica, leyenda [16, 9-23]

vid. leyenda

romántico español en verso, cuento [16, 9-23]

vid. cuento

Ros de Olano, Antonio

El doctor Lañuela (Antonio Ros de Olano) [16, 57-87]

"Historia verdadera" (Antonio Ros de Olano) [16, 57-87]

vid. historia

"La noche de las máscaras" (Antonio Ros de Olano) [16, 57-87] 
Rosbaco Marechal, Elbia

Mi vida con Leopoldo Marechal (Elbia Rosbaco Marechal) [8/9, 111-118] vid. vida

Rueda, Lope de

Comedia Armelina (Lope de Rueda) [17, 211-225]

vid. comedia

Eufemia (Lope de Rueda) [17, 211-225]

Medora (Lope de Rueda) [17, 211-225]

Ruiz de Alarcón, Juan

El Anticristo (Juan Ruiz de Alarcón) [11,93-112]

Rulfo, Juan

"Macario" (Juan Rulfo) [8/9, 213-218]

Saavedra, Ángel (duque de Rivas) [16, 9-23]

Safo de Lesbos [3, 5-13]

Saguier, Raquel

La vera historia de la Purificación (Raquel Saguier) [21/22, 61-78]

vid. historia

sainete

sainete dieciochesco de corte andaluz $[\mathbf{1 5}, 77-88]$

sainetil, género $[\mathbf{1 5}, 51-75]$

vid. género

Sainte-Maure, Benoît de

Roman de Troie (Benoît de Sainte-Maure) [23/24/25, 155-176]

vid. Troya

Salinas, Pedro

Cartas de amor a Margarita, 1912-1915 (Pedro Salinas) [6/7, 13-14] vid. cartas

Ensayos Completos (Pedro Salinas) [14, 73-78]

vid. ensayo

poesía amorosa de Pedro Salinas [14, 127-128]

vid. poesía

Todo más claro (Pedro Salinas) [14, 127-128]

Salutati, Coluccio

Salutati, Coluccio [23/24/25, 121-153]

Epistolae (Coluccio Salutati) [13, 19-31]

vid. epístola

Salvador, Álvaro

La condición del personaje (Álvaro Salvador) [10, 125-126] 


\section{vid. personaje}

Salvago, Javier

Los mejores años (Javier Salvago) [10, 127-131]

Samaniego, Félix María [15, 89-98]

Parodia de Guzmán el Bueno (Félix María de Samaniego) [15, 89-98]

Samblancat, Ángel [4, 43-47]

San Pedro, Diego de

Cárcel de Amor (Diego de San Pedro) [13, 193-206]

"Sant Sebastià" (Dalí, Salvador) [18, 101-113]

vid. Dalí, Salvador

Saramago, José

Ensayo sobre la ceguera (José Saramago) [14, 113-125]

vid. ensayo

sátira en Merimée [15, 159-168]

vid. Merimée, Prosper

Scipió e Aníbal (Antoni Canals) [23/24/25, 213-233]

vid. Canals, Antoni

Semanario Pintoresco Español (1836-1857) [16, 25-46]

Sender, Ramón J.

Contraataque (Ramón J. Sender) [5, 51-64]

Réquiem por un campesino español (Ramón J. Sender) [4, 69-75]

sentencia y anécdota [14, 113-125]

Sep Szarzynski, Mikolaj

"Epitaphium Rzyrnowi” (Mikolaj Sep Szarzynski) [11, 31-42]

Septiembre (Luis Muñoz) [10, 116-119]

vid. Muñoz, Luis

Sernesi, Silvano [1, 37-47]

sexualidad

"Dos palabras a mi sexo" (Casta Esteban y Navarro) [14, 65-71]

vid. Esteban y Navarro, Casta

homosexualidad y literatura [19/20, 257-280]

vid. literatura

sexual, misoginia [19/20, 75-93]

vid. misoginia

sexualidad [19/20, 9-20], [19/20, 111-139], [19/20, 219-237]

sexualidad femenina [19/20, 37-56]

sexualidad y géneros masculinos en la Edad Media [19/20, 21-35]

vid. género 
Unsex me here [19/20, 111-139]

El problema sexual (Rafael Barret) [21/22, 153-171]

vid. Barret, Rafael

silencio

Los nudos del silencio (Renée Ferrer) [21/22, 275-290]

vid. Ferrer, Renée

silencio femenino [21/22, 275-290]

silencio y comunicación [14, 93-102]

silencio, uso del [14, 93-102]

silencio, culturas y religiones [14, 93-102]

vid. religión

Tiempo de silencio (Luis Martín Santos) [5, 99-114]

vid. Martín Santos, Luis

Siloe, Gil de

retablo de Santa Ana (Gil de Siloe) [13, 207-216]

Silva, José Asunción

De sobremesa (José Asunción Silva) [8/9, 83-97]

Silva de varia lección (Pedro Mexía) [13, 285-314]

vid. Mexía, Pedro

simbolismo poético [21/22, 173-190]

vid. poética

Sobreviviente (Renée Ferrer) [21/22, 309-317]

vid. Ferrer, Renée

Soledades (Luis de Góngora y Argote) [11, 63-82]

vid. Góngora y Argote, Luis

Stravinski, Igor Fiodorovich

La consagración de la primavera (Igor Fiodorovich Stravinski) [2, 85-97]

Su único hijo (Leopoldo Alas “Clarín”) [1, 15-23], [6/7, 83-90]

vid. "Clarín" (Leopoldo Alas)

sueño

El precio de los sueños (Josefina Plá) [21/22, 173-190]

vid. Plá, Josefina

insomnio de amor [13, 285-314]

Lo somni (Bernat Metge) [13, 285-314]

vid. Metge, Bernat

somnium regis, somnium imperii [23/24/25, 93-119]

sиeño [5, 7-16], [11, 7-30], [23/24/25, 93-119]

sueño de Julio César [19/20, 21-35] 
sueño misterioso [16, 103-118]

sueño profético [23/24/25, 93-119]

sueño y ensoñación [21/22, 173-190]

sueños milagrosos [13, 285-314]

sueños y agüeros [13, 43-57]

Suicidios y otras muertes (Alfonso Costafreda) [1, 49-64]

vid. Costafreda, Alfonso

sujeto y cuerpo [19/20, 57-73]

vid. cuerpo

Surrealismo

Surrealismo [18, 25-39]

surrealista, automatismo [18, 87-99]

Tafur, Pero

Andanças e viajes (Pero Tafur) [13, 179-191]

vid. viaje

Talavera de Fracchia, Ida

Esto es andar (Ida Talavera de Fracchia) [21/22, 139-151]

Talodiqui, Demetrio [23/24/25, 121-153]

Tanhauser (Richard Wagner) [6/7, 65-71]

vid. Wagner, Richard

Tardes d'estiu (Dalí, Salvador) [18, 65-69]

vid. Dalí, Salvador

teatro

El gran teatro del mundo (Pedro Calderón de la Barca) [2, 99-109]

vid. Calderón de la Barca, Pedro

Le Théâtre de Clara Gazul (Prosper Merimée) [15, 159-168]

vid. Merimée, Prosper

teatro calderoniano $[\mathbf{1 7}, 279-292]$

teatro cómico breve [15, 51-75]

vid. cómico

teatro cómico breve español del Siglo de Oro [17, 227-261]

vid. cómico

teatro cortesano de festejos [17, 227-261]

teatro cortesano del siglo XVII [17, 33-46]

teatro e Iglesia [17, 65-87]

teatro en Sevilla en el Siglo de Oro [17, 65-87]

teatro español del siglo XVII [11, 125-139]

teatro mitológico [17, 279-292] 
vid. mito

teatro paraguayo del siglo XX [21/22, 191-200]

teatro popular del siglo XVII [17, 33-46]

teatro popular del siglo XVIII [15, 133-144]

teatro sentimental [15, 133-144]

Tejera, Juan Francisco [17, 177-209]

Las casas de Madrid (Juan Francisco Tejera) [17, 177-209] tema

tema del honor [13, 43-57]

temas de la literatura paraguaya [21/22, 51-59]

vid. literatura

temas estéticos [18, 13-23]

vid. estética

teoría queer [19/20, 9-20]

vid. queer

terrae incognitae [13, 179-191]

texto

intertextualidad y polifonía textual [21/22, 215-246]

paratexto literario [19/20, 37-56]

texto cartesiano [14, 31-45]

Tiempo de silencio (Luis Martín Santos) [5, 99-114]

vid. Martín Santos, Luis

Tierra de promisión (José Eustasio Rivera) [8/9, 249-254]

vid. Rivera, José Eustasio

Tipos madrileños (Carlos Frontaura) [16, 89-101]

vid. Frontaura, Carlos

Tirso de Molina (fray Gabriel Téllez)

El burlador de Sevilla (Tirso de Molina) [15, 99-120]

El castigo del penséque (Tirso de Molina) [11, 43-62]

El celoso prudente (Tirso de Molina) [11, 43-62]

El vergonzoso en palacio (Tirso de Molina) [11, 43-62]

Quien calla, otorga (Tirso de Molina) [11, 43-62]

Todo más claro (Pedro Salinas) [14, 127-128]

vid. Salinas, Pedro

tonadilla escénica $[\mathbf{1 5}, 77-88]$

Torre, Alfonso de la

"Non como quien se desvela" (Alfonso de la Torre) [13, 33-42] 
tradición clásica [23/24/25, 43-64]

traducción

traducción [23/24/25, 235-254], [23/24/25, 255-313]

traducción indirecta [23/24/25, 213-233]

traductológicas, Boccaccio, prácticas [23/24/25, 235-254]

vid. Boccaccio, Giovanni

traductológicas, Petrarca, prácticas [23/24/25, 235-254]

vid. Petrarca, Francesco

Trafalgar (Benito Pérez Galdós) [6/7, 73-81]

vid. Pérez Galdós, Benito

tragedia de corte histórico [17, 319-333]

vid. historia

translatio

translatio [23/24/25, 121-153]

translatio et compilatio $[\mathbf{2 3 / 2 4 / 2 5}, 11-41]$

vid. compilación

Translatio imperii [19/20, 21-35]

transmisión del mensaje filosófico [14, 31-45]

vid. filosofía

Trapiello, Andrés

Acaso una verdad (Andrés Trapiello) [10, 164-166]

tratado loimológico [13, 253-275]

"Tres morillas" [13, 277-284]

Tribagia (Juan del Encina) [13, 179-191]

vid. Encina, Juan del

Tristana (Benito Pérez Galdós) [19/20, 111-139]

vid. Pérez Galdós, Benito

Troya

Crónica Troyana (Juan Fernández de Heredia) [23/24/25, 65-91]

vid. crónica; Fernández de Heredia, Juan

Historia Destructionis Troiae (Guido delle Colonne) [23/24/25, 65-91],

[23/24/25, 155-176]

vid. historia

Roman de Troie (Benoît de Sainte-Maure) [23/24/25, 155-176]

vid. Sainte-Maure, Benoît de

Troya, materia de [23/24/25, 155-176], [23/24/25, 65-91]

troyanas, compilaciones [23/24/25, 155-176]

vid. compilatio 
Tucídides (Juan Fernández de Heredia) [23/24/25, 43-64]

vid. Fernández de Heredia, Juan

turpitudo y deformitas [15, 11-27]

Últimos domicilios (Joaquín Ríos) [10, 137-139]

vid. Ríos, Joaquín

Un aviador prevé su muerte (Justo Navarro) [5, 115-121]

vid. Navarro, Justo

Un crimen científico (José Fernández Bremón) [16, 119-132]

vid. Fernández Bremón, José

Un mundo para Julius (Alfredo Bryce Echenique) [8/9, 195-211]

vid. Bryce Echenique, Alfredo

Un perro andaluz (Luis Buñuel y Salvador Dalí) [18, 49-63]

vid. Buñuel, Luis; Dalí, Salvador

Una docena de cuentos (Narciso Campillo y Correa) [16, 133-142]

vid. cuento; Campillo y Correa, Narciso

Una mujer literata (José M. Gutiérrez de Alba) [15, 169-176]

vid. Gutiérrez de Alba, José M.; mujer

Unamuno, Miguel de [5, 31-36]

Unsex me here [19/20, 111-139]

vid. sexualidad

Urganda la desconocida [19/20, 75-93]

uso del silencio [14, 93-102]

vid. silencio

ut pictura poesis $[\mathbf{1 1}, 155-164]$

vid. poesía

Utrum Mortalitas [13, 253-275]

Valenciano, Juan Bautista [17, 133-159]

Valenciano, Juan Jerónimo [17, 133-159]

valores y derechos de la mujer [14, 65-71]

vid. mujer

Valter e Griselda (Bernat Metge) [23/24/25, 235-254]

vid. Metge, Bernat

Valle-Inclán, Ramón María del

La pipa de kif (Ramón María del Valle-Inclán) [3, 133-147]

Vallejo, César

Poemas póstumos (César Vallejo) [4, 97-106] 
vanguardia

vanguardia en Cataluña [18, 25-39]

vanguardia, poesía paraguaya de [21/22, 111-123]

vid. poesía

vanguardismo, posvanguardismo [21/22, 111-123]

Vargas Llosa, Mario

"El abuelo" (Mario Vargas Llosa) [8/9, 129-133]

Vega, Fray Pedro de [11, 247-256]

Veiravé, Alfredo [8/9, 267-281]

Versos y oraciones del caminante (León Felipe) [1, 25-35]

vid. Felipe, León

viaje

Andanças e viajes (Pero Tafur) [13, 179-191]

vid. Tafur, Pero

Primer viaje (Cristóbal Colón) [13, 179-191]

vid. Colón, Cristóbal

Viaje de Jerusalén (Fadrique Enríquez de la Ribera) [13, 179-191]

vid. Enríquez de la Ribera, Fadrique

Viaje nocturno (Juan Crisóstomo Centurión) [21/22, 79-96]

vid. Centurión, Juan Crisóstomo

viajes medievales, relatos de [13, 179-191]

vid. relato

vicios y virtudes $[13,33-42]$

vida

1942. Vida y tiempos de Juan Cabezón de Castilla (Homero Aridjis) [8/9, 135-150] vid. Aridjis, Homero

La vida de frontera (Carlos Marzal) [10, 154-157]

vid. Marzal, Carlos

Libro de la Vida (Teresa de Jesús) [19/20, 57-73]

vid. Cepeda y Ahumada, Teresa (Teresa de Jesús); libro

Mi vida con Leopoldo Marechal (Elbia Rosbaco Marechal) [8/9, 111-118]

vid. Rosbaco Marechal, Elbia

Vida de Alejandro Magno [23/24/25, 255-313]

vid. Alexandre

Vida del buscón llamado Pablos (Francisco de Quevedo) [6/7, 73-81]

vid. Quevedo y Villegas, Francisco de

vida fronteriza [13, 59-65]

Vida secreta de Salvador Dali (Salvador Dalí) [18, 41-47], [18, 65-69] 
vid. Dalí, Salvador

Vidas de monjas [19/20, 57-73]

Vidas de hombres ilustres (Juan Fernández de Heredia) [23/24/25, 121-153]

vid. Fernández de Heredia, Juan

Vidas españolas e hispanoamericanas del siglo XIX (colección literaria) [6/7, 133-144]

Vidas Paralelas (Plutarco) [23/24/25, 121-153]

vid. Plutarco

Vidas semblantes [23/24/25, 255-313]

Villalba, Juan Manuel

Fondo (Juan Manuel Villalba) [10, 149-151]

Villalba, Shirley

Penumbra hembra y otros desencuentros (Shirley Villalba) [21/22, 319-327]

Villaviciosa, Sebastián de

El retrato de Juan Rana (Sebastián de Villaviciosa) [17, 227-261]

Villiers de l'Isle-Adam, Auguste [12, 129-151]

Virgilio Marón, Publio

Virgilio Marón, Publio [3, 14-23]

Eneida (Publio Virgilio Marón) [17, 263-277]

visión

visión cosmológica [21/22, 309-317]

visiones espirituales [13, 285-314]

voz poética femenina [21/22, 319-327]

vid. poética

Wagner, Richard

Tanhauser (Richard Wagner) [6/7, 65-71]

Wiezell, Elsa

"Canto Libertario" (Elsa Wiezell) [21/22, 125-138]

Wittgenstein, Ludwig

Investigaciones filosóficas (Ludwig Wittgenstein) [14, 79-89]

vid. filosofía

Yo el Supremo (Augusto Roa Bastos) [8/9, 171-188], [21/22, 33-49], [21/22, 247-257]

vid. Roa Bastos, Augusto

Yo el supremo / El trueno entre las hojas (Augusto Roa Bastos) [21/22, 61-78]

vid. Roa Bastos, Augusto

Yourcenar, Marguerite

Alexis o el tratado del inútil combate (Marguerite Yourcenar) [2, 5-9] 
Zamora, Antonio de

No hay plazo que no se cumpla ni deuda que no se pague, y convidado de piedra (Antonio de Zamora) [15, 99-120]

zarzuela y género chico $[15,77-88]$

vid. género

Zorrilla, José

Don Juan Tenorio (José Zorrilla) [6/7, 65-71], [15, 99-120]

Zurita, Raúl

Purgatorio [8/9, 283-290]

Canto a su amor desaparecido [8/9, 283-290] 